\title{
Is cultural taste in Finland acquired from mother, father or both
}

\author{
Seppo Suominen \\ Haaga-Helia University of Applied Sciences \\ Hietakummuntie 1 A, FIN-00700 Helsinki, Finland \\ Tel. +358 29 4471138, E-mail: seppo.suominen@haaga-helia.fi
}

\begin{abstract}
The main goal of this paper is to address the importance of parental cultural taste in explaining cultural participation among older adults in Finland. The study considers the intergenerational transfer hypothesis and asks: Do middle-aged or older consumers inherit cultural tastes from their parents? How stable are these intergenerational transfer effects? Which parental hobbies are the most influential? A constant elasticity of substitution (CES) utility function is used to describe the structure of consumer preferences. The linear demand system to be estimated uses the seemingly unrelated systems (SUR) method with two equations. If the intergenerational transfer hypothesis is valid, parental interest in movies, pop music, classical music and visual arts should have a positive impact on their children's demand for movies, rock or jazz music, classical music and art gallery visits, respectively. The results indicate that the intergenerational transfer hypothesis is valid. Children do indeed inherit their cultural habits and taste from their parents. We seem to visit similar cultural events to those that our parents do or did. The youngest age cohort is by far the most influenced by parental interest in classical music. The visual arts and pop music interests of parents seem to be second and third most influential hobbies but only when the youngest age cohorts are considered. Parental pop music and sport hobbies are the most influential sources when the cultural and sports participation of the middle-aged are studied. A mother's visual arts interests and father's sports interests are most important determinants of the cultural and sports participation decisions of the oldest age cohort. In general age, gender and education are important determinants of cultural participation. The youngest, who have less family constraints, are more active than the middle-aged and those over 55 are more active participants - except for filmgoing or rock music. Theatre attendance, arts gallery visits and classical music concert visits increase after age 45. Attending musicals is not dependent on education while all other cultural events are elite in terms of education, except rock music concerts, which well-educated parents, attend less than the reference group, which is students. Women are more active in all cultural activities studied here. Most of the intergenerational transfer effects are not stable throughout the child's age. Only a mother's classical music or visual art habits seem to have a stable and positive effect on the classical music concert participation and on the art gallery visits of the child regardless of age. However, a father's corresponding classical music or visual art habits have a positive effect on their children, when they are aged between 15 and 35, attending classical music concerts and going to art galleries.
\end{abstract}

Keywords: Intergenerational transfer, Cultural participation, Finland, CES.

DOI: $10.7176 / \mathrm{JCSD} / 62-07$

Publication date: November $30^{\text {th }} 2020$

\section{Introduction and motivation}

The main goal of this paper is to address the importance of parental cultural taste in explaining cultural participation among adults in Finland. It is well known that some cultural tastes are influenced by parental taste rather than social position although that is not always the case. For example, in Israel a father's status has a positive relationship to a taste for classical music, opera, blues and jazz (Katz-Gerro, Raz and Yaish 2007). Furthermore, children from highly educated and wealthy parents are more active in cultural participation than children with loweducated and less wealthy parents (van Eijck 1997, Nagel 2010). Media behaviour and watching artistic programmes on television seem to be predicted by parental choices when the respondents were about 15 years old (Vettehen, Konig, Westerik and Beentjes 2012). Pop and rock music concert participation and the educational level of the mother also seem to have a significant effect on the pop and rock participation of adolescents in Flanders while for the father these effects are not significant (Willekens and Lievens 2014). To the knowledge of the author, no such research that would explain cultural participation according to parental cultural taste has been done using the Finnish data and an economic model.

Many have used parental education as a proxy for cultural capital because a higher education is associated with the ability to understand and enjoy the symbolic message of cultural goods (e.g. Katz-Gerro, Raz and Yaish 2007 or Willekens and Lievens 2014) Highly educated parents seem to transfer this ability to their children, who then 
consume more cultural events and performances that are more elitist, like classical music concerts and opera performances, as young consumers. The word "transfer" should be understood by the notion of inheriting.

However, it is not known how this intergenerational transfer hypothesis is valid if the consumer is older. Thus, the purpose of this study is to study intergenerational transfer with regard to older consumers of culture.

This study uses data collected by Statistics Finland in 2007, which focuses on the cultural attitudes of citizens in Finland, excluding the Åland islands. A letter of inquiry was sent to 3000 randomly selected individuals and there were 1388 respondents, meaning that the response rate is $46.3 \%$. The data allows the study of how intergenerational transfer explains cultural participation. The data also allows us to study a similar intergenerational transfer hypothesis for sports activity. In particular, the aim of this study is to provide an analysis of the effects of intergenerational transfer effects on the type of cultural events and sports participation of older consumers. The empirical analysis is based on an economic model, which is used to justify the variables used in the estimations. The theory highlights the idea of utility received through consumption even if the available monetary resources limit consumption. Some policy recommendations are made based on the empirical analysis.

The second chapter contains a literature review and the setting of the research question. An economic model is presented in the third chapter. Data and some prescriptive analyses are provided before the results of the empirical analysis are presented. Policy recommendations are made in the conclusion.

\section{Literature review}

Cultural taste or cultural consumption is associated with a consumer's own education, income and profession (Seaman 2006, 419). Performing arts audiences are elite in terms of education and income. The relatively highly educated and wealthy seem to consume more highbrow arts but different terminologies have been used to classify the tastes. The classification into highbrow and lowbrow has often been used in cultural sociology. For example, Bihagen and Katz-Gerro (2000) show that women are more active in highbrow consumption (opera, dance or theatrical performances), whereas men are active in lowbrow consumption, such as watching television (entertainment, sport). Another classification that focuses on the variety of cultural consumption and which has been widely used is the omnivore and univore hypothesis. In this hypothesis, the main line of classification does not lie between highbrow and lowbrow, instead the omnivore is said to engage in both high art and popular culture and is more inclusive and the univore is more one-sided and exclusive (Warde, Wright and Gayo-Cal 2008). Based on several studies, Peterson (2005) concludes that the highly educated and middle-class seem to participate in both high and popular culture. In Finland women and older age groups are more involved in highbrow arts, except filmgoing (Purhonen, Gronow and Rahkonen 2011). Moreover, Purhonen et al. (2011) point out that education but not income - is a highly important determinant in highbrow culture consumption. However, the younger and highly educated do not seem to engage in highbrow culture as much as highly educated older Finns do.

If cultural consumption is a normal good from the point of economic view, higher incomes should result in higher demand, but lost income due to time spent on these leisure activities should then decrease the demand. The impact of personal incomes on the demand for the time-consuming consumption of art has two channels, the direct income effect and the indirect substitution effect. The adverse effect of rising wages on demand is the negative substitution effect, the time needed for consumption is more expensive in terms of lost income. This substitution effect is called Linder's effect (Linder 1970). The adverse effect of rising wages has not been given much attention in the literature but Løyland and Ringstad (2009), using Norwegian data, suggest that Linder's effect is important and cannot be ignored regarding sports. Furthermore, an adverse effect has been shown to be valid for sports, filmgoing and classical music concerts (Suominen 2015). The income-leisure approach proposes that time-consuming sports participation varies positively with incomes and negatively with earnings per hour. If the lost income aspect is not taken into account, the insignificance of the income variable, which has been reported in some studies (Seaman 2006 or Purhonen et al 2011, Palma, Palma and Aguado 2013), can be rationalised. Indeed, Seaman emphasizes that the role of education is much stronger than the role of income.

The theory of socialisation used by sociologists and educationalists explains how individuals inherit habits and norms from parents, friends and school (Handel 2006). Parents influence their children's behaviour by giving them support and guidance. The active involvement of parents serves to advance their children's cultural interest (Banks 2012). Habits, norms and manners become accepted in societies as they are learned not just from parents but also from friends and school. Children are open to primary socialisation as they learn values and habits from their parents and friends. Secondary socialisation takes place in schools and leisure time activities as pupils and friends 
are socialised to act according to school and leisure time rules - if a child spends plenty of time outside the home, the role of schoolmates and friends becomes more important.

Adolescents and young adults reading habits, i.e. the reading of fiction, is also strongly influenced by the parental reading habits. Students whose parents are enthusiastic readers seem to read much more than their schoolmates whose parents read less (Nagel and Verboord 2012). The influence of parental reading habits is rather stable and for reading the notion of intergenerational transfer is valid and has previously been found to occur in the Netherlands (Nagel and Verboord 2012), however, a household income variable was not included as an explanatory variable. Nevertheless, the intergenerational transfer hypothesis that focuses on primary socialisation has received much empirical support (van Eijck 1997, Katz-Gerro, Raz and Yaish 2007, Oskala, Keaney, Chan and Bunting 2009, Nagel 2010, Vettehen, Konig, Westerik and Beentjes 2012, Palma, Palma and Aguado 2013 and Willekens and Lievens 2014). However, the focus in most studies is on adolescents or young adults, and it is not known how this intergenerational transfer hypothesis is valid for middle-aged and older consumers.

De Graaf and Kalmijn (2001) argue that intergenerational transfer has two main channels. The direct channel is related to the economic status of parents and children and has a role that declines as the indirect channel of educational attainment becomes stronger. In addition, the direct transmission of occupations across generations has declined since direct inheritance in labour markets has substantially diminished and meant that the indirect transmission of social class through the educational system has also become less important since the educational system is based more on individual achievement and not on inheritance - or class as sociologists define it. Nevertheless, highbrow culture consuming parents actively transfer cultural habits to their children by arranging art gallery and theatre visits and dance classes. Reeves (2015) shows that parents encourage their children to play musical instruments since this transfer improves family cohesion. Willekens, Deanekindt and Lievens (2014) also show that the relative effect of the education that one's parents received differs for art and heritage because the mother's influence seems to be more important while the role of father seems to dominate regarding pop and rock activities. Thus, it is important to separately study the influence of the father and the influence of mother on participation in cultural events.

Highly educated people have a greater information processing capacity and they seem to seek cultural activities that offer more complex and multidimensional experiences. Hence educated consumers participate more in highbrow cultural events (Notten, Lancee, van de Werfhorst and Ganzeboom 2015). It has also been noted that the highly educated are more omnivore and participate both in highbrow and lowbrow cultural activities (Purhonen, Gronow and Rahkonen 2010), i.e. they are not genre specific in their tastes.

Intergenerational transfer is more likely to originate from the father than from the mother regarding sports activity among older cohorts (Suominen 2015) but when the child is middle-aged or younger, the influence of both parents is equally important. Regarding filmgoing or classical music concerts, the mother's influence is significant among all age cohorts while the cultural activities engaged in by fathers do not seem to be inherited once a person moves beyond 55 years of age.

To sum up, we can form some research questions:

1) Do middle-aged or older consumers inherit their cultural tastes from their parents?

2) How stable are these intergenerational transfer effects in terms of different age groups?

3) Are there any differences regarding inheriting culture from mothers and fathers?

4) Which types of parental hobbies are the most influential?

All of these questions are important in better understanding how we inherit cultural consumption patterns from our parents. The stability of the effects refers to permanence over time, from childhood to old age.

\section{A model explaining cultural consumption}

According to García, Lera-López and Suárez (2011), consumer preferences are understood in terms of time spent on different leisure activities $\left(l_{1}\right.$ and $\left.l_{s}\right)$ and net income $(\mathrm{m})$. Net income can be used to measure consumption that is not related to leisure and it can be used to measure items other than leisure related consumption. Leisure is used 
in sport $\left(l_{s}\right)$ and cultural activities $\left(l_{1}\right)$ like filmgoing, museum visits, attending rock, classical or jazz music concerts, musicals, opera or visiting theatres or art exhibitions. The linear demand system can be estimated using the seemingly unrelated systems (SUR) method with two equations. Therefore, in each estimation only two of the above listed leisure activities are jointly evaluated. A constant elasticity of substitution (CES) utility function is used to describe the structure of consumer preferences due to the convenient marginal rate of substitution (MRS) features. The consumer's optimisation problem is

$$
\text { (1) } \max _{m, l_{1}, l_{s}} U\left(m, l_{s}, l_{1}\right)=\left[m^{-\rho}+\beta l_{s}^{-\rho}+\gamma l_{1}^{-\rho}\right]^{-\frac{1}{\rho}} \text { s.t. } \quad m=w\left(T-l_{s}-l_{1}\right)+y
$$

Where $\mathrm{U}$ denotes utility, $\beta$ and $\gamma$ are positive parameters, $\mathrm{w}$ is hourly earnings, T is time available (e.g. 168 hours a week) and finally $\mathrm{y}$ is non-labour income. The elasticity of substitution is $\frac{1}{1+\rho}, \rho>-1$. By solving the optimisation problem including the budget constraint - $m=w\left(T-l_{s}-l_{1}\right)+y-$ the consumer's demand for sports $\left(l_{s}\right)$ and cultural activities $\left(l_{l}\right)$ can be obtained. The interior solutions of the maximisation problem indicate that the MRS between net income $(m)$ and either sports or cultural activities must be equal to the hourly earnings:

$$
\begin{aligned}
\text { (2) } M R S_{m, l_{s}}= & \frac{\partial U / \partial l_{s}}{\partial U / \partial m}=\beta\left(\frac{m}{l_{s}}\right)^{1+\rho}=w \\
\text { (3) } M R S_{m, l_{1}}= & \frac{\partial U / \partial l_{1}}{\partial U / \partial m}=\gamma\left(\frac{m}{l_{1}}\right)^{1+\rho}=w
\end{aligned}
$$

Equations (2) and (3) denote that the marginal rate of substation between any two components in the CES utility function are not dependent on the third. For the empirical estimation, two useful expressions can be derived from (2) and (3)

$$
\begin{aligned}
& \text { (4) } \log \left(\frac{m}{l_{s}}\right)=\frac{1}{1+\rho} \log w-\frac{1}{1+\rho} \log \beta \\
& \text { (5) } \log \left(\frac{m}{l_{1}}\right)=\frac{1}{1+\rho} \log w-\frac{1}{1+\rho} \log \gamma
\end{aligned}
$$

The observable and unobservable factors that have an impact on leisure activities are captured through the parameters $\beta$ and $\gamma$ as follows:

$$
\begin{aligned}
& \text { (6) } \beta=e^{\left(Z_{s} \theta_{s}+\varphi_{S}\right)} \\
& \text { (7) } \gamma=e^{\left(Z_{1} \theta_{1}+\varphi_{1}\right)}
\end{aligned}
$$

where $Z_{s}$ and $Z_{1}$ represent different socio-economic variables that have an impact on utility and leisure time activities and $\varphi_{s}$ and $\varphi_{1}$ are random variables that account for unobservable factors. Assuming that $\varphi_{s}$ and $\varphi_{1}$ are distributed as a bivariate normal distribution with zero means and constant variances, the linear system can be estimated using the seemingly unrelated systems (SUR) method. The following equations can be estimated:

$$
\begin{aligned}
& \text { (8) } \log \left(\frac{m}{l_{s}}\right)=\frac{1}{1+\rho} \log w-\frac{1}{1+\rho}\left(Z_{s} \theta_{s}+\varphi_{s}\right) \\
& \text { (9) } \log \left(\frac{m}{l_{1}}\right)=\frac{1}{1+\rho} \log w-\frac{1}{1+\rho}\left(Z_{1} \theta_{1}+\varphi_{1}\right)
\end{aligned}
$$

The sports participation $\left(l_{s}\right)$ and cultural activities demand $\left(l_{l}\right)$ are the denominators on the left-hand side of equations (8) and (9) denoting that any positive sign in the result of the estimation demonstrates the negative impact of the explanatory variable on the sport or cultural consumption. Due to this, the estimation results have been reversed.

\section{Data and descriptive statistics}

The data (Culture and Leisure in Finland 2007) were collected in autumn 2007 by Statistics Finland using a postal inquiry sent to 3000 adult (aged 18-74) individuals in Finland, excluding the Åland islands. The response rate was $46.3 \%$. The data represent a wide survey on culture and leisure, providing information on personal and household 
incomes, education, age, gender, marital status, family relations, cultural and sports participation. Table 1 (below) presents a summary of the statistics on the forms of cultural and sports participation.

The most common leisure activity is sports since roughly $80 \%$ of the respondents exercise at least one a month. Approximately $15 \%$ exercise daily, women are more active than men. In the sample, the most common cultural activity is filmgoing. Roughly $6 \%$ of men and $8 \%$ of women go to a cinema every month or more often and almost $40 \%$ of men and $50 \%$ of women go to a cinema at least a few times in a year. Theatre attendance is second. Every fourth man and $43.5 \%$ of women go to the theatre at least a few times a year. Opera, classical and jazz music concerts are the cultural events least participated in. Museum visits, rock music concerts, musicals and art gallery visits fall between the other activities in terms of attendance. There is no statistical difference between genders regarding the attending of rock music or jazz music concerts, otherwise women are more active cultural events participants.

A commensurate measure for the demand of any cultural activity (say filmgoing) is defined and calculated as follows: "How often do you go to ...?" About once a week $=3$ hours per week; About once a month $=0.5$ hours per week; A few times a year $=0.1$ hours per week; Less often $=0.01$ hours per week; Never $=0.001$ hours per week. The measure for sports $\left(1_{s}\right)$ is calculated in the following way: "Every day" is recoded 4 hours per week, several times a week, once a week, two to three times a month or once a month, two hours, one hour, 0.5 hours, 0.1 hours per week, respectively and less frequently is recoded 0.01 hours per week. In this study the dependent variable's $\log \left(\frac{m}{l_{s}}\right)$ or $\log \left(\frac{m}{l_{1}}\right)$ nominator is the (logarithm of) net household incomes and the denominator if the (logarithm of) the demand for sports $\left(1_{s}\right)$ or the demand for other leisure activities (cinema, museum, etc.) as defined above.

The following socio-economic covariates available and used in this study are gender, education, age. The reference education alternative is not having any professional or vocational education. Age is classified by using ten-year ranges starting from 15 to 24 and ending at "older than 65". The reference range that is not used in the estimations is 35 to 44 years old. The reason for using the ranges is the assumption that family constraints due to parenting are likely to be highest when the parents are between 25 and 44 and that family constraints will presumably reduce any leisure activity. We assume that the leisure activity to age relationship is neither linear nor quadratic. The personal and household net income variables in the survey have some zero responses, the missing data is estimated by assuming that incomes are determined by education, gender, age, weekly working hours and marital status. The results can be found in the Appendix.

The sport exercise question in the data is dichotomous: "Do you do any sports exercise or physical activity?" If the answer was "no", the respondent was asked to skip the next question: "How often do you exercise? For at least 30 minutes so that you are out of breath or sweat?" The exact response numbers are presented in Table 1. Roughly $20 \%$ do not do any exercise. Therefore, there is a lack of information about the demand for sports ("How often do you exercise...?"). This may result in endogeneity of the demand variable. Following García, Lera-López and Suárez (2011) the estimation method first uses a dichotomous probit model for the probability of exercise: any sports or physical activity and uses the inverse Mills ratio to avoid the potential endogeneity problem. The sports demand equation (8) in the demand system ( 8 and 9) is estimated using SUR and by including the inverse Mills ratio. A similar procedure is used to estimate the working hours per week and the sample includes pensioners and the unemployed and people who do not correspond to the working hours per week question (roughly $43 \%$ in the sample). A probit model for the probability of being employed is estimated and the inverse Mills ratio is obtained. This Mills ratio is included to estimate working hours per week and these estimated coefficients for the working hours per week are predicted for each cohort person in the sample. The results of the probability of doing any sports exercise, the probability of being employed and working hours per week are given in the tables in the Appendix. Table 2 (below) defines the variables and the descriptive statistics used in the demand system. The missing observations of the dependent variables have been replaced with "never".

The descriptive statistics show that the average household monthly net incomes (after income taxes), taking into account the estimated values if the observation is zero in the original data, is less than $€ 2800$. The original data is reported using 10 different levels, the net incomes after taxes: $1=$ less than $€ 500 /$ month, $\ldots 10=$ more than $€ 10000 /$ month. The interval midpoint is used for each observation. The average personal net income is lower than the household incomes as expected. We can get the earnings per hour by dividing the personal net incomes with the working hours per week (times 4) which is about $€ 22$ on average in this study. Approximately $50 \%$ of the respondents in the sample have either a vocational school or college education. Respondents with a master's degree 
is the third largest group in the classification on the basis of the education while $19 \%$ have no professional education, meaning that they are either students or they have only basic education.

The intergenerational transfer variables in the questionnaire are asked with the following questions: "If you think about your childhood, were your parents interested in the listed hobbies?" There are separate questions concerning the mother and father. More than $50 \%$ of the respondent's mothers were interested in reading while the father's reading habit was somewhat less than $50 \%$. Attending movies at a cinema was second most often mentioned if both genders are taken into account. There is a big difference in sports as a hobby between father and mother. Almost $45 \%$ of the respondents mention that their father was interested in sport while the share of mothers interested in sport is about $11 \%$. The Spearman correlation coefficients of parents' hobbies shown in Table 3 reveals that the hobbies do not generally overlap. However, it is more common that both parents seem to have had a similar interest. The largest positive correlation coefficients appear in pop music $\left(\rho_{\mathrm{f}: \mathrm{pop}, \mathrm{m} \text { :pop }}=0.44\right)$, filmgoing $\left(\rho_{\text {f:movies, }}\right.$ :movies $\left.=0.41\right)$ and classical music $\left(\rho_{\text {f:classical, } \mathrm{m} \text { : classical }}=0.37\right)$. The sport and reading habits of fathers seem to have a slightly negative correlation ( $\rho_{\text {frreading, f:sport }}=-0.22$ ) and the visual arts and classical music habits of mothers are positively correlated $\left(\rho_{\mathrm{m}: \text { visual arts, m:classical music }}=0.39\right)$.

\section{Results}

If the intergenerational transfer hypothesis is valid, the parents' interest in filmgoing, pop music, classical music and visual arts should have a positive impact on the demand for filmgoing, rock or jazz music, classical music and art gallery visits, respectively. In Tables 4, 5 and 6 (below) the estimation results are presented. The coefficient signs have been reversed in order to show the results in a more easily understood way.

The estimation results show that both a father's and a mother's filmgoing have an impact on the respondent's filmgoing demand. Parental interest in pop music has a positive influence on the demand for rock music. The coefficient that reveals a father's pop music interest on his child's rock music concert participation is 0.353 and the corresponding figure for a mother's influence is 0.333 . The pop music interest of both father and mother have a partial effect on jazz and classical music demand, which are selective since the mother's pop music taste has an impact on jazz music demand but the father's pop music preference does not, while the reverse is valid in the case of classical music. A father's interest in pop music is important and a mother's pop music interest is not. In general Linder's effect is important since rising wages seem to diminish the demand for all leisure activities - the coefficient of $\log \mathrm{w}$ is statistically positive in each demand function.

However, the household incomes in the dependent variable $\log \left(\frac{m}{l_{1}}\right)$ and the hourly wage of the respondent are related and therefore the Linder's effect explanation must be interpreted with caution. In Table 4 the estimation results for filmgoing, rock, jazz and classical music are presented. In the demand system the first equation is always the demand for filmgoing. In Table 5 museum, opera, theatre and musical demand equations are shown. Filmgoing is favoured by younger, female and highly educated consumers. Rock music is not favoured by consumers who have either a vocational, college education or a master's degree in relation to students with a basic education. The age structure of rock music concert participants is similar to cinema-goers. Jazz music is not favoured by persons who have either vocational, college or bachelor level education, while those who are older than 45 seem to favour jazz while they do not favour movies or rock. Classical music is elite in terms of education and the middle-aged do not seem to favour classical music. Opera is more elite in terms of education than classical music and it seems that the estimated threshold age is higher for opera visits than for classical music. The age structure of opera participants and musicals is similar but opera is more elite in terms of education than musicals. The education variable is not significant for musicals.

In Table 6 the demand results for going to art galleries and sports are presented. Art gallery and museum visits seem to have a similar customer structure, which is not surprising due to their overlapping profile. Most of them have paintings and sculptures inside. In contrast, sport is totally different in terms of age structure and education. The youngest and oldest age cohorts are more active in their sports participation.

In Tables 4, 5 and 6 the intergenerational transfer hypothesis is tested using parental filmgoing and pop or classical music interests as explanatory variables. The results of all available parents' hobbies as explanatory variables are presented in Table 7. Only the intergenerational transfer variables are shown in Table 7. In each SUR estimation, there are two equations and the first is always filmgoing and interest of the father and mother in filmgoing is included in the estimations. Otherwise the remaining equation is different (pop, jazz, classical, museum, opera, 
theatre, musical, art gallery or sport) and one of the combinations of the parents' interests is included: reading, pop, classical, visual arts or sports.

The leisure activities that received the most intergenerational transfer influences are art gallery visits (8), filmgoing (7) and opera (7). Art gallery visits are positively influenced by both of the parents' reading habits, classical music and visual arts interests, a mother's filmgoing interest also has a positive impact while a mother's sports interest has a negative effect on the demand for art gallery visits. Filmgoing is positively influenced by the father's filmgoing and sports habits, while the mother's reading, filmgoing, pop music, classical music and visual art interests have an influence on filmgoing demand of her children. Attending jazz music events, sport and musicals are least influenced by parental hobbies. A mother's classical and pop music preferences have an impact on the respondent's jazz music events participation. Lastly, visual art and sport are most likely to have no influence on each other.

The third (3) research question asks about inheriting taste from one's father or mother. The results shown above indicate that the mother's influence is stronger than the father's. There are substantial differences because it would appear that, for example, a mother's reading habits have multiple effects on her child's cultural participation while the father's reading habits have less influence. In contrast, the sports participation of the father seems to be more influential than the mother's.

The fourth (4) research question concerns the most influential cultural taste passed on by the parents. A mother's reading habits and classical music preferences are the "most" influential intergenerational transfer effect sources. If a respondent's mother has (has had) a reading habit, then the respondent is more likely to favour art gallery visits, filmgoing, opera, classical music, museums, theatre and rock music events. If the respondent's father has (has had) a reading habit, the influence is more restricted, only the demand for art gallery and classical music increases.

In general the intergenerational transfer hypothesis is verified. Both a father's and mother's visual art preference have a positive impact on art gallery and museum visits. Parental classical music preferences influence the respondent's opera and classical music demand as well as art gallery and museum visits. Parental filmgoing has a positive impact on the respondent's cinema demand while participation in sports is also inherited.

All statistically significant intergenerational transfer effects are listed in Table 8 (below).

In addition, Table 8 reveals that jazz music, sport and musicals are the most "individual" events. They are the least influenced by parental hobbies. Jazz music participation is influenced only by the mother's classical or pop music tastes. If a mother has an interest in classical or pop music then the respondent is more likely to participate in jazz music events, however, a mother who favours classical and pop music can also have an impact on filmgoing. Sport is positively influenced only by the father's or mother's sports activity and negatively by a father who favours the visual arts. Attending musicals is somewhat less influenced by parental hobbies rather than theatre visits in general. Only a mother's preference for pop music and sports and a father's preference for filmgoing have an impact on their children attending musicals while the intergenerational transfer sources for theatre visits are more varied. A mother's classical music and reading habits predict theatre visits.

The first (1) and second (2) research questions raised at the beginning of the study are related to how this intergenerational transfer hypothesis is valid among different age categories and how stable these effects are. Therefore, a separate analysis is carried out by using three subsamples: the youngest (from 15 to $34, \mathrm{n}=383$ ), middle-aged (from 35 to $54, \mathrm{n}=496$ ) and the oldest (older than 55, $\mathrm{n}=509$ ). The results are shown in Table 9 (below). Only the coefficients of the intergenerational transfer variables are presented.

In general, the coefficients of the intergenerational transfer source variables in Table 7 seem to be the averages of the coefficients listed in Table 9. Regarding filmgoing and a mother's reading habit the coefficient is $0.268^{* *}$ and the corresponding coefficient for each age group is $0.342^{(*)}, 0.261^{(*)}$ and 0.217 , respectively, indicating that the oldest age group's movie attendance is not influenced by a mother's reading habits. The "most" influential sources that have an effect on the cultural participation of a young $(15-34)$ respondent are the father's classical music (8) interest and the mother's classical music (7) interest. Visual arts and pop music habits are second and third on the list. A parental filmgoing habit has the least effect on a young consumer's cultural participation decisions. Pop music and sport would appear to be the most influential source when the middle-aged are analysed. Classical music comes third on the list but the father's reading habit has no effect on the participation of middle-aged consumers in cultural events, while a mother's reading habit is rather influential. In the case of middle-aged persons, parental filmgoing has the least impact on cultural participation decisions although filmgoing is a rather influential on older 
persons. The oldest age cohort seems to be most influenced by a mother's visual arts interest. All other cultural categories except rock music, musicals and sports are affected by the visual arts interest of the respondent's mother. However, the father's visual arts interest has no effect at all on the cultural or sport habits of the oldest cohort in the sample.

A mother's reading habit seems to have a stable effect on theatre or art gallery visits - regardless of the age group and if a mother is or has been an active consumer of literature, then the child is more likely to visit the theatre or art galleries. If the mother is not an active consumer of literature, then the respondent is less likely to visit theatres or art galleries. A father's sports habit has a positive effect on his children's sports habit regardless of the child's age. Therefore, the intergenerational transfer effect is stable. A father's pop music habit has an effect on the sports activity of the child, although this changes from positive (young, middle-aged) to negative when the children is getting older (the oldest cohort). Classical music participation and art gallery visits are influenced by the mother's classical music or visual arts habit and this effect is very strong and consistent throughout the child's life and is independent of the age. A mother's visual arts hobby also has a stable effect on her children's museum or opera visits.

\section{Conclusion}

The results indicate that the intergenerational transfer hypothesis is valid. We do indeed inherit cultural habits and taste from our parents. We seem to visit similar cultural events to those of our parents. The youngest age cohort is by far the most influenced by parental classical music interests. The visual arts and pop music interest of the parents are the second and third most influential hobbies but only when the youngest ages are considered. A parents' pop music and sport hobbies are the most influential sources on the cultural and sports participation of the middle-aged cohort studied. A mother's visual arts interest and a father's sports interest are most important roots of the cultural and sport participation decisions of the oldest age cohort. These results emphasize that some intergenerational transfer effects are stable and significant, i.e. young consumers and also middle-aged and older consumers continue with the tastes they inherited from their parents.

Age, gender and education are important determinants of cultural participation. This is in line with previous results (for example van Eijck 1997, Katz-Gerro, Raz and Yaish). The youngest have fewer family constraints and are more active than the middle-aged and older cohorts, except for filmgoing. Theatre attendance, art gallery visits and classical music concert visits increase after 45 years age. Visiting musicals is not dependent on education while all other cultural events are elite in terms of education. The only exception is rock music concerts, which the more educated seem to visit less than the reference group - students. Women are more active in all the cultural activities studied here. The $\chi^{2}$ statistics shown in Table 1 illustrate that there are no gender differences in rock and jazz music participation but the results in Table 4 indicate that women are more active participants at rock or jazz music concerts when all other relevant participation related variables have been taken into account.

The constant elasticity of the substation (CES) utility function is used here to model the leisure activities demand. The structure of consumer preferences is CES since the estimation equations are mathematically convenient and the interpretation of the variable coefficients are fairly clear. Since the cultural or sports participation variable is in the denominator of each equation, the principle of interpretation is reverse: a negative coefficient is interpreted positively. The positive coefficient of the hourly wage variable therefore means that lost income has a negative effect on demand regarding cultural participation decisions.

Most of the intergenerational transfer effects are not stable throughout life. Only a mother's classical music or visual art habits seem to have a stable and positive effect on classical music concert participation and on the art gallery visits of their children regardless of age. In contrast, the father's corresponding classical music or visual art habits have a positive effect on classical music concert participation or on the art gallery visits of their children only when the children are rather young. This suggests that mothers and fathers have differing influences.

The results presented here must be interpreted with caution since the data are not time-series data. In particular, the long-run effects must be evaluated with care since parental tastes are measured based on what their children remember. However, the measure is dichotomous, i.e. the respondent's father or mother showed interest in the topics. This increases the relevance of the measure.

Some cultural policy recommendations can be drawn from these results. Since we seem to inherit our cultural participation habits from our parents it is important that children have other channels from which to inherit taste. A useful channel is school, both primary and secondary school should use time and money to visit museums, theatres, concerts and so on. Such channels should aim to include large, heterogeneous sets of individuals who 
would not otherwise participate because their parents did not participate. The democratisation of culture needs intervention so that all citizens are able to enrich their cultural identity. We should subsidise not just performances in the cities but also allocate resources so that national institutions can tour extensively and take cultural events to underserved areas and families. From the viewpoint of aesthetics such a public policy is imperative. Indeed, the impact of such interventionist policies should be studied more thoroughly in the future. Moreover, a similar research should be carried out in other countries since Finland or other Scandinavian countries is a high-income society and the income equality is very low. It is possible that income inequality might have an impact on the results and using data from other countries might reveal dissimilar effects.

\section{References}

Banks, Patricia Ann (2012): Cultural Socialization in Black Middle-Class Families. Cultural Sociology 6, 61 - 73

De Graag, Paul M. and Matthijs Kalmijn (2001): Trends in the Intergenerational Transmission of Cultural and Economic Status. Acta Sociologica 44, 51 - 66

Handel, Gerard (2006): Childhood socialization. $2^{\text {nd }}$ Edition. New Brunswick. Aldine Transaction.

Katz-Gerro, Tally, Sharon Raz and Meir Yaish (2007): Class, status, and the intergenerational transmission of musical tastes in Israel. Poetics 35, 152-167

Linder, Staffan (1970): The harried leisure class. New York: Columbia University Press.

Løyland, Knut and Vidar Ringstad (2009): On the Price and Income Sensitivity of the Demand for Sports: Has Linder's Disease Become More Serious? Journal of Sports Economics, 10, 601 - 618

Nagel, Ineke (2010): Cultural Participation Between the Ages of 14 and 24: Intergenerational Transmission or Cultural Mobility? European Sociological Review 26, 541-556

Nagel, Ineke and Marc Verboord (2012): Reading behaviour from adolescence to early adulthood: A panel study of the impact of family and education on reading fiction books. Acta Sociologica 55, 351-365

Notten, Natascha, Bram Lancee, Herman G. van de Werfhorst and Harry B.G. Ganzeboom (2015): Educational stratification in cultural participation: cognitive competence or status motivation? Journal of Cultural Economics, $39,177-203$

Oskala, Anni, Emily Keaney, Tak Wing Chan and Catherine Bunting (2009): Encourage children today to build audiences for tomorrow. Evidence from the Taking Part survey on how childhood involvement in the arts affects arts engagement in adulthood. Arts Council England, March 2009.

Palma, María Luisa, Luis Palma and Luis Fernando Aguado (2013): Determinants of cultural and popular celebration attendance: the case study of Seville Spring Fiestas. Journal of Cultural Economics, 37, 87 - 107

Peterson, Richard A. (2005): Problems in comparative research: The example of omnivorousness. Poetics 33, $257-$ 282

Purhonen, Semi, Jukka Gronow and Keijo Rahkonen (2010): Nordic democracy of taste? Cultural omnivorousness in musical and literary taste prefereces in Finland. Poetics 38, 266 - 298

Purhonen, Semi, Jukka Gronow and Keijo Rahkonen (2011): Highbrow culture in Finland: Knowledge, taste and participation. Acta Sociologica 54, 385-402

Seaman, Bruce A. (2006): Empirical Studies of Demand for the Performing Arts. Ch 14 in Handbook of the Economics of Art and Culture, ed. By Victor A. Ginsburgh and David Thorsby. North-Holland

Suominen, Seppo (2015): The intergenerational transfer effects on sport activity. Athens Journal of Sports 2, 6984

van Eijck, Koen (1997): The impact of family background and educational attainment on cultural participation: A sibling analysis. Poetics 25, 195-224. 
van Hek, Margriet and Gerbert Kraaykamp (2015): How do parents affect cultural participation of their children? Poetics, http://dx.doi.org/10.1016/j.poetic.2015.06.001

Warde, Alan, David Wright and Modesto Gayo-Cal (2008): The omnivorous orientation in the UK. Poetics 36, $148-165$

Vettehen, Paul Hedriks, Ruben P. Konig, Henk Westerik and Hans Beentjes (2012): Explaining television choices: The influence of parents and partners. Poetics 40, 565- 585

Willekens, Mart and John Lievens (2014): Family (and) culture: The effect of cultural capital within the family on the cultural participation of adolescents. Poetics 42, 98-113

Willekens, Mart, Stijn Daenekindt and John Lievens (2014): Whose Education Matters More? Mothers' and Fathers' Education and the Cultural Participation of Adolescents. Cultural Sociology 8, 291 - 309

\begin{tabular}{|c|c|c|c|c|c|c|c|}
\hline & & $\begin{array}{l}\text { Approximately } \\
\text { every week } \\
\text { (3) }\end{array}$ & $\begin{array}{l}\text { Approximately } \\
\text { every month } \\
(0.5) \\
\end{array}$ & $\begin{array}{l}\text { A few times } \\
\text { in a year } \\
(0.1)\end{array}$ & $\begin{array}{l}\text { Less often } \\
(0.01)\end{array}$ & $\begin{array}{l}\text { Never } \\
(0.001)\end{array}$ & $\begin{array}{l}\text { Different } \\
\text { between } \\
\text { genders: }\end{array}$ \\
\hline Filmgoing & $\begin{array}{l}\text { Men: } 564 \\
\text { Women: } 792\end{array}$ & $\begin{array}{l}\text { M: } 0.5 \% \\
\text { W: } 0.9 \%\end{array}$ & $\begin{array}{l}\text { M: } 5.3 \% \\
\text { W: } 7.3 \%\end{array}$ & $\begin{array}{l}\text { M: } 32.1 \% \\
\text { W: } 41.0 \%\end{array}$ & $\begin{array}{l}\text { M: } 48.0 \% \\
\text { W: } 43.9 \%\end{array}$ & $\begin{array}{l}\text { M: } 14.0 \% \\
\text { W: } 6.8 \%\end{array}$ & $\begin{array}{l}\chi^{2} \\
28.229^{* * *}\end{array}$ \\
\hline Museums & $\begin{array}{l}\text { M: } 563 \\
\text { W: } 790\end{array}$ & $\begin{array}{l}\text { M: } 0.0 \% \\
\text { W: } 0.2 \%\end{array}$ & $\begin{array}{l}\text { M: } 1.8 \% \\
\text { W: } 3.0 \%\end{array}$ & $\begin{array}{l}\text { M: } 21.7 \% \\
\text { W: } 26.5 \%\end{array}$ & $\begin{array}{l}\text { M: } 55.6 \% \\
\text { W: } 56.5 \%\end{array}$ & $\begin{array}{l}\text { M: } 21.0 \% \\
\text { W: } 13.8 \%\end{array}$ & $\begin{array}{l}\chi^{2}= \\
16.679^{* * *}\end{array}$ \\
\hline $\begin{array}{l}\text { Rock music } \\
\text { concerts }\end{array}$ & $\begin{array}{l}\text { M: } 560 \\
\text { W: } 784\end{array}$ & $\begin{array}{l}\text { M: } 0.2 \% \\
\text { W: } 0.4 \%\end{array}$ & $\begin{array}{l}\text { M: } 0.9 \% \\
\text { W: } 1.7 \%\end{array}$ & $\begin{array}{l}\text { M: } 12.5 \% \\
\text { W: } 15.8 \%\end{array}$ & $\begin{array}{l}\text { M: } 36.6 \% \\
\text { W: } 33.4 \%\end{array}$ & $\begin{array}{l}\text { M: } 49.8 \% \\
\text { W: } 48.7 \%\end{array}$ & $\chi^{2}=5.411$ \\
\hline Opera & $\begin{array}{l}\text { M: } 558 \\
\text { W: } 787\end{array}$ & $\begin{array}{l}\text { M: } 0.0 \% \\
\text { W: } 0.0 \%\end{array}$ & $\begin{array}{l}\text { M: } 0.0 \% \\
\text { W: } 0.6 \%\end{array}$ & $\begin{array}{l}\text { M: } 3.0 \% \\
\text { W: } 7.2 \%\end{array}$ & $\begin{array}{l}\text { M: } 20.3 \% \\
\text { W: } 27.8 \%\end{array}$ & $\begin{array}{l}\text { M: } 76.7 \% \\
\text { W: } 64.3 \%\end{array}$ & $\begin{array}{l}\chi^{2}= \\
28.825^{\text {*** }}\end{array}$ \\
\hline $\begin{array}{l}\text { Classical } \\
\text { music } \\
\text { concerts } \\
\end{array}$ & $\begin{array}{l}\text { M: } 558 \\
\text { W: } 787\end{array}$ & $\begin{array}{l}\text { M: } 0.0 \% \\
\text { W: } 0.3 \%\end{array}$ & $\begin{array}{l}\text { M: } 0.9 \% \\
\text { W: } 2.3 \%\end{array}$ & $\begin{array}{l}\text { M: } 5.2 \% \\
\text { W: } 10.7 \%\end{array}$ & $\begin{array}{l}\text { M: } 22.5 \% \\
\text { W: } 26.6 \%\end{array}$ & $\begin{array}{l}\text { M: } 71.4 \% \\
\text { W: } 60.2 \%\end{array}$ & $\begin{array}{l}\chi^{2}= \\
25.373^{* * *}\end{array}$ \\
\hline $\begin{array}{l}\text { Jazz music } \\
\text { concerts }\end{array}$ & $\begin{array}{l}\text { M: } 557 \\
\text { W: } 782\end{array}$ & $\begin{array}{l}\text { M: } 0.0 \% \\
\text { W: } 0.0 \%\end{array}$ & $\begin{array}{l}\text { M: } 0.9 \% \\
\text { W: } 0.5 \%\end{array}$ & $\begin{array}{l}\text { M: } 4.1 \% \\
\text { W: } 5.1 \%\end{array}$ & $\begin{array}{l}\text { M: } 20.5 \% \\
\text { W: } 21.1 \%\end{array}$ & $\begin{array}{l}\text { M: } 74.5 \% \\
\text { W: } 73.3 \%\end{array}$ & $\chi^{2}=1.523$ \\
\hline Musicals & $\begin{array}{l}\text { M: } 554 \\
\text { W: } 784\end{array}$ & $\begin{array}{l}\text { M: } 0.0 \% \\
\text { W: } 0.3 \%\end{array}$ & $\begin{array}{l}\text { M: } 0.2 \% \\
\text { W: } 0.3 \%\end{array}$ & $\begin{array}{l}\text { M: } 4.7 \% \\
\text { W: } 11.5 \%\end{array}$ & $\begin{array}{l}\text { M: } 35.2 \% \\
\text { W: } 49.4 \%\end{array}$ & $\begin{array}{l}\text { M: } 59.9 \% \\
\text { W: } 38.6 \%\end{array}$ & $\begin{array}{l}\chi^{2}= \\
64.683^{* * *}\end{array}=$ \\
\hline Theatre & $\begin{array}{l}\text { M: } 562 \\
\text { W: } 793\end{array}$ & $\begin{array}{l}\text { M: } 0.0 \% \\
\text { W: } 0.3 \%\end{array}$ & $\begin{array}{l}\text { M: } 2.7 \% \\
W: 3.0 \%\end{array}$ & $\begin{array}{l}\text { M: } 21.7 \% \\
\text { W: } 40.2 \%\end{array}$ & $\begin{array}{l}\text { M: } 48.9 \% \\
\text { W: } 45.6 \%\end{array}$ & $\begin{array}{l}\text { M: } 26.7 \% \\
\text { W: } 10.4 \%\end{array}$ & $\begin{array}{l}\chi^{2}= \\
84.389^{* * *}\end{array}$ \\
\hline Art galleries & $\begin{array}{l}\text { M: } 559 \\
\text { W: } 783\end{array}$ & $\begin{array}{l}\text { M: } 0.4 \% \\
\text { W: } 1.0 \% \\
\end{array}$ & $\begin{array}{l}\text { M: } 2.1 \% \\
\text { W: } 3.2 \% \\
\end{array}$ & $\begin{array}{l}\text { M: } 14.1 \% \\
\text { W: } 18.9 \% \\
\end{array}$ & $\begin{array}{l}\text { M: } 35.4 \% \\
\text { W: } 41.8 \% \\
\end{array}$ & $\begin{array}{l}\text { M: } 47.9 \% \\
\text { W: } 35.1 \% \\
\end{array}$ & $\begin{array}{l}\chi^{2}= \\
24.214^{* * *}=\end{array}$ \\
\hline $\begin{array}{l}\text { Exercise any } \\
\text { sports }\end{array}$ & $\begin{array}{l}\text { M: } 555 \\
\text { W: } 790 \\
\end{array}$ & $\begin{array}{l}\text { Yes, M: } 76.8 \% \\
\text { Yes, W: } 86.5 \%\end{array}$ & $\begin{array}{l}\text { No, M: } 23.2 \% \\
\text { No, W: } 13.6 \% \\
\end{array}$ & & & & $\begin{array}{l}\chi^{2}= \\
21.196^{* * *}=\end{array}$ \\
\hline & & $\begin{array}{l}\text { Daily }+ \text { several } \\
\text { times a week } \\
(4 \text { or } 2)\end{array}$ & $\begin{array}{l}\text { Once a week } \\
\text { (1) }\end{array}$ & $\begin{array}{l}2-3 \text { times a } \\
\text { month } \\
(0.5)\end{array}$ & $\begin{array}{l}\text { Once a } \\
\text { month } \\
(0.1)\end{array}$ & $\begin{array}{l}\text { Less often } \\
(0.01)\end{array}$ & \\
\hline $\begin{array}{l}\text { Sports: How } \\
\text { often? }\end{array}$ & $\begin{array}{l}\text { M: } 442 \\
\text { W: } 697\end{array}$ & $\begin{array}{l}\text { M: } 19.2 \%+47.5 \% \\
\text { W: } 19.4 \%+53.1 \%\end{array}$ & $\begin{array}{l}\text { M: } 20.6 \% \\
\text { W: } 19.5 \%\end{array}$ & $\begin{array}{l}\text { M: } 7.0 \% \\
\text { W: } 5.5 \% \\
\end{array}$ & $\begin{array}{l}\text { M: } 2.7 \% \\
\text { W: } 1.1 \%\end{array}$ & $\begin{array}{l}\text { M: } 2.9 \% \\
\text { W: } 1.4 \% \\
\end{array}$ & $\chi^{2}=9.721^{(*)}$ \\
\hline
\end{tabular}

Table 1: Participation or visits to certain cultural activities and sports activities in Finland 2007, percentages, $M$ $=$ men, $\mathrm{W}=$ women - the gender impact on engagement in cultural or sports activities tested with $\chi^{2}$-statistics. 


\begin{tabular}{|c|c|c|c|c|}
\hline Variables & Type & & Mean & $\begin{array}{l}\text { Standard } \\
\text { deviation }\end{array}$ \\
\hline Dependent variables & & & \multicolumn{2}{|c|}{$\begin{array}{l}\text { Statistics before taking } \\
\text { logarithms }\end{array}$} \\
\hline \multirow[t]{2}{*}{$\log \left(m / l_{\text {sport }}\right)$} & $\begin{array}{l}\text { Logarithm, } \mathrm{m} \sim \\
\text { scale, } €\end{array}$ & $\begin{array}{l}\mathrm{m}=\text { household monthly salaries if known }(\mathrm{n}=1026) \text {, otherwise } \\
\text { estimated }(\mathrm{n}=362)\end{array}$ & 2768.31 & 1825.81 \\
\hline & $\begin{array}{l}1_{\mathrm{s}} \sim \text { scale, } \\
\text { hours/week }\end{array}$ & $\begin{array}{l}1_{\mathrm{s}}=[0.001-4] \text { depending on "How often do you exercise? For at } \\
\text { least } 30 \text { minutes so that you are at least out of breath or sweat? }\end{array}$ & 1.66 & 1.27 \\
\hline $\log \left(m / l_{\text {movie }}\right)$ & $\begin{array}{l}1_{\text {movie }} \sim \\
\text { scale, } \\
\text { hours/week }\end{array}$ & $\begin{array}{l}1_{\text {movie }}=[0.001-3] \text { depending on "How often do you go to see a } \\
\text { movie at a cinema?" }\end{array}$ & 0.094 & 0.274 \\
\hline $\log \left(m / l_{\text {museum }}\right)$ & $\begin{array}{l}1_{\text {classical music }} \sim \\
\text { scale, } \\
\text { hours/week }\end{array}$ & $\begin{array}{l}1_{\text {museum }}=[0.001-3] \text { depending on "How often do you go to a } \\
\text { museum?" }\end{array}$ & 0.041 & 0.140 \\
\hline $\log \left(m / l_{\text {rock music }}\right)$ & $\begin{array}{l}1_{\text {rock music }} \sim \text { scale, } \\
\text { hours/week }\end{array}$ & $\begin{array}{l}1_{\text {rock music }}=[0.001-3] \text { depending on "How often do you go to rock } \\
\text { music concerts?" }\end{array}$ & 0.029 & 0.172 \\
\hline $\log \left(m / l_{\text {opera }}\right)$ & $\begin{array}{l}1_{\text {opera }} \sim \\
\text { scale, } \\
\text { hours/week }\end{array}$ & $\begin{array}{l}1_{\text {opera }}=[0.001-3] \text { depending on "How often do you go to the } \\
\text { opera?" }\end{array}$ & 0.010 & 0.036 \\
\hline $\log \left(m / l_{\text {classical music }}\right)$ & $\begin{array}{l}1_{\text {classical music }} \sim \\
\text { scale, } \\
\text { hours/week }\end{array}$ & $\begin{array}{l}1_{\text {classical music }}=[0.001-3] \text { depending on "How often do you go to } \\
\text { classical music concerts?" }\end{array}$ & 0.024 & 0.132 \\
\hline $\log \left(m / l_{j a z z \text { music }}\right)$ & $\begin{array}{l}l_{\text {jazz music }} \sim \text { scale } \\
\text { hours/week }\end{array}$ & $\begin{array}{l}1_{\text {jazz music }}=[0.001-3] \text { depending on "How often do you go to jazz } \\
\text { music concerts?" }\end{array}$ & 0.024 & 0.132 \\
\hline $\log \left(m / l_{\text {musical }}\right)$ & $\begin{array}{l}1_{\text {musical }} \sim \text { scale, } \\
\text { hours/week }\end{array}$ & $\begin{array}{l}1_{\text {musicac }}=[0.001-3] \text { depending on "How often do you go to } \\
\text { classical musicals?" }\end{array}$ & 0.014 & 0.118 \\
\hline $\log \left(m / l_{\text {theatre }}\right)$ & $\begin{array}{l}1_{\text {theatre }} \sim \text { scale, } \\
\text { hours/week }\end{array}$ & $\begin{array}{l}1_{\text {theatre }}=[0.001-3] \text { depending on "How often do you go to theatre } \\
\text { performances?" }\end{array}$ & 0.054 & 0.142 \\
\hline $\log \left(m / l_{\text {art gallery }}\right)$ & $\begin{array}{l}l_{\text {art gallery }} \sim \text { scale, } \\
\text { hours/week }\end{array}$ & $\begin{array}{l}l_{\text {art gallery }}=[0.001-3] \text { depending on "How often do you visit art } \\
\text { galleries?" }\end{array}$ & 0.052 & 0.265 \\
\hline \multicolumn{5}{|l|}{ Independent variables } \\
\hline \multirow[t]{2}{*}{$\begin{array}{l}\log w=\log (\text { monthly } \\
\text { salary/working hours } x \text { ) }\end{array}$} & $\begin{array}{l}\text { Logarithm, } \\
\text { w=hourly wage } \\
\sim \text { scale, } €\end{array}$ & Personal monthly salary & 2531.40 & 1982.04 \\
\hline & & Working hours per week & 28.30 & 15.61 \\
\hline Vocational education & Binary & 2 or 3 years after secondary school & 0.295 & 0.456 \\
\hline College & Binary & 2 or 3 years after secondary or upper secondary school & 0.230 & 0.421 \\
\hline Bachelor & Binary & 3 or 4 years after upper secondary school & 0.097 & 0.295 \\
\hline Master & Binary & 2 or 3 years after gaining a Bachelor's degree & 0.166 & 0.371 \\
\hline Doctor & Binary & At least 4 years after gaining a Master's degree & 0.022 & 0.145 \\
\hline Female & Binary & & 0.587 & 0.493 \\
\hline Age $15-24$ & Binary & & 0.109 & 0.311 \\
\hline Age $25-34$ & Binary & & 0.167 & 0.373 \\
\hline Age $35-44$ & & Reference, excluded from the estimations & 0.171 & 0.377 \\
\hline Age $45-54$ & Binary & & 0.186 & 0.389 \\
\hline Age $55-64$ & Binary & & 0.228 & 0.419 \\
\hline Age 65 - & Binary & & 0.139 & 0.346 \\
\hline Father interested: Reading & Binary & & 0.485 & 0.449 \\
\hline Movies & Binary & & 0.265 & 0.441 \\
\hline Pop music & Binary & & 0.176 & 0.381 \\
\hline Classical music & Binary & & 0.103 & 0.305 \\
\hline Visual arts & Binary & & 0.076 & 0.265 \\
\hline Sport & Binary & & 0.449 & 0.497 \\
\hline Mother interested: Reading & Binary & & 0.543 & 0.498 \\
\hline Movies & Binary & & 0.229 & 0.420 \\
\hline Pop music & Binary & & 0.186 & 0.389 \\
\hline Classical music & Binary & & 0.113 & 0.317 \\
\hline Visual arts & Binary & & 0.138 & 0.345 \\
\hline Sport & Binary & & 0.113 & 0.317 \\
\hline
\end{tabular}

Table 2: Variables used in the study and descriptive statistics 


\begin{tabular}{|l|l|l|l|l|l|l|l|l|l|l|l|l|}
\hline & F: R & $\begin{array}{l}\text { F: } \\
\text { M }\end{array}$ & F: P & F: C & F: V & F: S & $\begin{array}{l}\text { M: } \\
\text { R }\end{array}$ & M:M & M:P & M:C & M:V & M:S \\
\hline F: Reading & 1 & 0.16 & - & 0.18 & 0.14 & - & 0.14 & 0.12 & - & 0.14 & 0.07 & 0.02 \\
\hline F: Movies & & 1 & 0.21 & 0.12 & 0.16 & 0.14 & 0.16 & $\mathbf{0 . 4 1}$ & 0.18 & 0.11 & 0.09 & 0.09 \\
\hline F: Pop music & & & 1 & 0.02 & 0.05 & 0.11 & 0.10 & 0.10 & $\mathbf{0 . 4 4}$ & 0.02 & 0.03 & 0.10 \\
\hline $\begin{array}{l}\text { F: Classical } \\
\text { m }\end{array}$ & & & 1 & 0.27 & - & 0.09 & 0.05 & - & $\mathbf{0 . 3 7}$ & 0.16 & 0.02 \\
\hline F: Visual arts & & & & & 1 & 0.02 & 0.12 & 0.19 & 0.04 & 0.24 & 0.26 & 0.02 \\
\hline F: Sports & & & & & & 1 & 0.13 & 0.11 & 0.18 & 0.04 & 0.08 & 0.20 \\
\hline M: Reading & & & & & & & 1 & 0.19 & 0.09 & 0.21 & 0.18 & 0.03 \\
\hline M: Movies & & & & & & & & 1 & 0.21 & 0.07 & 0.10 & 0.13 \\
\hline M: Pop music & & & & & & & & & 1 & 0.04 & 0.07 & 0.12 \\
\hline $\begin{array}{l}\text { M: Classical } \\
\text { m }\end{array}$ & & & & & & & & & 1 & $\mathbf{0 . 3 9}$ & 0.03 \\
\hline $\begin{array}{l}\text { M: Visual } \\
\text { arts }\end{array}$ & & & & & & & & & & & 1 & 0.02 \\
\hline M: Sports & & & & & & & & & & & & 1 \\
\hline
\end{tabular}

Table 3: The correlation coefficients of parents' hobbies 


\begin{tabular}{|c|c|c|c|c|c|c|c|c|}
\hline & Filmgoing & Rock music & Jazz music & $\begin{array}{l}\text { Classical } \\
\text { music }\end{array}$ & Movies & Rock music & Jazz music & $\begin{array}{l}\text { Classical } \\
\text { music }\end{array}$ \\
\hline $\log w$ & $\begin{array}{l}-0.335^{* * *} \\
(0.038)\end{array}$ & $\begin{array}{l}-0.369^{* * *} \\
(0.239)\end{array}$ & $\begin{array}{l}-0.413^{* * *} \\
(0.162)\end{array}$ & $\begin{array}{l}-0.361^{* * *} \\
(0.037)\end{array}$ & $\begin{array}{l}-0.339^{* * * *} \\
(0.038)\end{array}$ & $\begin{array}{l}-0.372^{* * *} \\
(0.041)\end{array}$ & $\begin{array}{l}-0.417^{* * *} \\
(0.028)\end{array}$ & $\begin{array}{l}-0.363^{* * *} \\
(0.036)\end{array}$ \\
\hline $\begin{array}{l}\text { Vocational } \\
\text { education }\end{array}$ & $\begin{array}{l}0.020 \\
(0.128)\end{array}$ & $\begin{array}{l}-0.322^{*} \\
(0.137)\end{array}$ & $\begin{array}{l}-0.176^{(*)} \\
(0.093)\end{array}$ & $\begin{array}{l}-0.067 \\
(0.126)\end{array}$ & $\begin{array}{l}0.030 \\
(0.128)\end{array}$ & $\begin{array}{l}-0.318^{*} \\
(0.137)\end{array}$ & $\begin{array}{l}-0.167^{(*)} \\
(0.093)\end{array}$ & $\begin{array}{l}-0.043 \\
(0.122)\end{array}$ \\
\hline College & $\begin{array}{l}0.103 \\
(0.137)\end{array}$ & $\begin{array}{l}-0.431^{* *} \\
(0.147)\end{array}$ & $\begin{array}{l}-0.280^{* *} \\
(0.100)\end{array}$ & $\begin{array}{l}0.142 \\
(0.135)\end{array}$ & $\begin{array}{l}0.104 \\
(0.137)\end{array}$ & $\begin{array}{l}-0.420^{* *} \\
(0.148)\end{array}$ & $\begin{array}{l}-0.275^{* *} \\
(0.100)\end{array}$ & $\begin{array}{l}0.142 \\
(0.131)\end{array}$ \\
\hline Bachelor & $\begin{array}{l}0.440^{*} \\
(0.176)\end{array}$ & $\begin{array}{l}-0.145 \\
(0.188)\end{array}$ & $\begin{array}{l}-0.265^{*} \\
(0.128)\end{array}$ & $\begin{array}{l}0.452^{* * *} \\
(0.173)\end{array}$ & $\begin{array}{l}0.415^{*} \\
(0.176)\end{array}$ & $\begin{array}{l}-0.137 \\
(0.189)\end{array}$ & $\begin{array}{l}-0.283^{*} \\
(0.128)\end{array}$ & $\begin{array}{l}0.349^{*} \\
(0.169)\end{array}$ \\
\hline Master & $\begin{array}{l}0.623^{* * *} \\
(0.148)\end{array}$ & $\begin{array}{l}-0.441^{* *} \\
(0.158)\end{array}$ & $\begin{array}{l}0.084 \\
(0.107)\end{array}$ & $\begin{array}{l}1.126^{* * *} \\
(0.145)\end{array}$ & $\begin{array}{l}0.553^{* * *} \\
(0.149)\end{array}$ & $\begin{array}{l}-0.477^{* *} \\
(0.160)\end{array}$ & $\begin{array}{l}0.032 \\
(0.108)\end{array}$ & $\begin{array}{l}0.945^{* * *} \\
(0.143)\end{array}$ \\
\hline Doctor & $\begin{array}{l}1.073^{* * * *} \\
(0.306)\end{array}$ & $\begin{array}{l}-0.429 \\
(0.326)\end{array}$ & $\begin{array}{l}0.267 \\
(0.222)\end{array}$ & $\begin{array}{l}1.456^{* * * *} \\
(0.300)\end{array}$ & $\begin{array}{l}0.978^{* * *} \\
(0.306)\end{array}$ & $\begin{array}{l}-0.492 \\
(0.329)\end{array}$ & $\begin{array}{l}0.193 \\
(0.222)\end{array}$ & $\begin{array}{l}1.261^{* * * *} \\
(0.293)\end{array}$ \\
\hline Female & $\begin{array}{l}0.396^{* * * *} \\
(0.087)\end{array}$ & $\begin{array}{l}0.235^{*} \\
(0.093)\end{array}$ & $\begin{array}{l}0.166^{* *} \\
(0.063)\end{array}$ & $\begin{array}{l}0.527^{* * * *} \\
(0.085)\end{array}$ & $\begin{array}{l}0.411^{* * *} \\
(0.087)\end{array}$ & $\begin{array}{l}0.259^{*} \\
(0.093)\end{array}$ & $\begin{array}{l}0.176^{* *} \\
(0.063)\end{array}$ & $\begin{array}{l}0.529^{* * *} \\
(0.083)\end{array}$ \\
\hline Age $15-24$ & $\begin{array}{l}1.597^{* * * *} \\
(0.171)\end{array}$ & $\begin{array}{l}1.390^{* * * *} \\
(0.183)\end{array}$ & $\begin{array}{l}0.705^{* * *} \\
(0.124)\end{array}$ & $\begin{array}{l}0.674^{* * *} \\
(0.168)\end{array}$ & $\begin{array}{l}1.607^{* * *} \\
(0.172)\end{array}$ & $\begin{array}{l}1.431^{* * * *} \\
(0.184)\end{array}$ & $\begin{array}{l}0.720^{* * *} \\
(0.124)\end{array}$ & $\begin{array}{l}0.679^{* * * *} \\
(0.164)\end{array}$ \\
\hline Age $25-34$ & $\begin{array}{l}0.679^{* * * *} \\
(0.150)\end{array}$ & $\begin{array}{l}0.720^{* * *} \\
(0.160)\end{array}$ & $\begin{array}{l}-0.003 \\
(0.109) \\
\end{array}$ & $\begin{array}{l}-0.177 \\
(0.147)\end{array}$ & $\begin{array}{l}0.715^{* * *} \\
(0.149)\end{array}$ & $\begin{array}{l}0.779^{* * *} \\
(0.160)\end{array}$ & $\begin{array}{l}0.023 \\
(0.108)\end{array}$ & $\begin{array}{l}-0.122 \\
(0.143)\end{array}$ \\
\hline Age $45-54$ & $\begin{array}{l}-0.264^{(*)} \\
(0.142)\end{array}$ & $\begin{array}{l}-0.260^{(*)} \\
(0.151)\end{array}$ & $\begin{array}{l}0.170^{(*)} \\
(0.103)\end{array}$ & $\begin{array}{l}0.288^{*} \\
(0.139) \\
\end{array}$ & $\begin{array}{l}-0.280^{*} \\
(0.142)\end{array}$ & $\begin{array}{l}-0.271^{(*)} \\
(0.152)\end{array}$ & $\begin{array}{l}0.159 \\
(0.103)\end{array}$ & $\begin{array}{l}0.281^{*} \\
(0.136)\end{array}$ \\
\hline Age $55-64$ & $\begin{array}{l}-0.349^{*} \\
(0.139)\end{array}$ & $\begin{array}{l}-0.374^{*} \\
(0.148)\end{array}$ & $\begin{array}{l}0.347^{* * *} \\
(0.100)\end{array}$ & $\begin{array}{l}0.742^{* * *} \\
(0.136)\end{array}$ & $\begin{array}{l}-0.390^{* *} \\
(0.138)\end{array}$ & $\begin{array}{l}-0.429^{* *} \\
(0.148)\end{array}$ & $\begin{array}{l}0.317^{* *} \\
(0.100)\end{array}$ & $\begin{array}{l}0.716^{* * *} \\
(0.132)\end{array}$ \\
\hline Age 65 - & $\begin{array}{l}0.405^{*} \\
(0.179)\end{array}$ & $\begin{array}{l}0.503^{* * *} \\
(0.192)\end{array}$ & $\begin{array}{l}1.453^{* * * *} \\
(0.130)\end{array}$ & $\begin{array}{l}1.937^{* * * *} \\
(0.176)\end{array}$ & $\begin{array}{l}0.339 \\
(0.179)^{(*)}\end{array}$ & $\begin{array}{l}0.420^{*} \\
(0.192)\end{array}$ & $\begin{array}{l}1.405^{\text {**** }} \\
(0.130)\end{array}$ & $\begin{array}{l}1.868^{* * * *} \\
(0.171)\end{array}$ \\
\hline \multicolumn{9}{|l|}{$\begin{array}{l}\text { Father: Reading } \\
\text { interested }\end{array}$} \\
\hline \multicolumn{9}{|l|}{$\begin{array}{l}\text { Mother: Reading } \\
\text { interested }\end{array}$} \\
\hline $\begin{array}{l}\text { Father: Filmgoing } \\
\text { interested }\end{array}$ & $\begin{array}{l}0.229^{*} \\
(0.107)\end{array}$ & $\begin{array}{l}-0.002 \\
(0.115)\end{array}$ & $\begin{array}{l}0.035 \\
(0.078)\end{array}$ & $\begin{array}{l}0.040 \\
(0.106)\end{array}$ & $\begin{array}{l}0.246^{*} \\
(0.107)\end{array}$ & $\begin{array}{l}0.059 \\
(0.115)\end{array}$ & $\begin{array}{l}0.042 \\
(0.077)\end{array}$ & $\begin{array}{l}-0.010 \\
(0.102)\end{array}$ \\
\hline $\begin{array}{l}\text { Mother: } \\
\text { Filmgoing } \\
\text { interested }\end{array}$ & $\begin{array}{l}0.268^{*} \\
(0.112)\end{array}$ & $\begin{array}{l}0.054 \\
(0.120)\end{array}$ & $\begin{array}{l}0.003 \\
(0.081)\end{array}$ & $\begin{array}{l}0.139 \\
(0.110)\end{array}$ & $\begin{array}{l}0.315^{* *} \\
(0.111)\end{array}$ & $\begin{array}{l}0.121 \\
(0.119)\end{array}$ & $\begin{array}{l}0.041 \\
(0.080)\end{array}$ & $\begin{array}{l}0.150 \\
(0.106)\end{array}$ \\
\hline $\begin{array}{l}\text { Father: Pop music } \\
\text { interested }\end{array}$ & $\begin{array}{l}0.199 \\
(0.127)\end{array}$ & $\begin{array}{l}0.353^{* *} \\
(0.135)\end{array}$ & $\begin{array}{l}0.135 \\
(0.092)\end{array}$ & $\begin{array}{l}0.321^{* *} \\
(0.124)\end{array}$ & & & & \\
\hline $\begin{array}{l}\text { Mother: Pop } \\
\text { music interested }\end{array}$ & $\begin{array}{l}0.315^{*} \\
(0.124) \\
\end{array}$ & $\begin{array}{l}0.333^{*} \\
(0.133) \\
\end{array}$ & $\begin{array}{l}0.243^{* *} \\
(0.090)\end{array}$ & $\begin{array}{l}0.157 \\
(0.122) \\
\end{array}$ & & & & \\
\hline $\begin{array}{l}\text { Father: Classical } \\
\text { music interested }\end{array}$ & & & & & $\begin{array}{l}0.086 \\
(0.150)\end{array}$ & $\begin{array}{l}0.208 \\
(0.161)\end{array}$ & $\begin{array}{l}0.172 \\
(0.109)\end{array}$ & $\begin{array}{l}0.565^{* * *} \\
(0.144)\end{array}$ \\
\hline $\begin{array}{l}\text { Mother: Classical } \\
\text { music interested }\end{array}$ & & & & & $\begin{array}{l}0.443^{* *} \\
(0.144)\end{array}$ & $\begin{array}{l}0.010 \\
(0.155)\end{array}$ & $\begin{array}{l}0.258^{*} \\
(0.105)\end{array}$ & $\begin{array}{l}0.916^{* * * *} \\
(0.138)\end{array}$ \\
\hline \multicolumn{9}{|l|}{$\begin{array}{l}\text { Father: Visual } \\
\text { arts interested }\end{array}$} \\
\hline \multicolumn{9}{|l|}{$\begin{array}{l}\text { Mother: Visual } \\
\text { arts interested }\end{array}$} \\
\hline \multicolumn{9}{|l|}{$\begin{array}{ll}\text { Father: } & \text { Sports } \\
\text { interested } & \\
\end{array}$} \\
\hline \multicolumn{9}{|l|}{$\begin{array}{ll}\text { Mother: } & \text { Sports } \\
\text { interested } & \end{array}$} \\
\hline constant & $\begin{array}{l}-10.843^{* * *} \\
(0.224) \\
\end{array}$ & $\begin{array}{l}-12.431^{* * * *} \\
(0.239) \\
\end{array}$ & $\begin{array}{l}-12.987^{* * *} \\
(0.162) \\
\end{array}$ & $\begin{array}{l}-13.224^{* * * *} \\
(0.220)\end{array}$ & $\begin{array}{l}-10.787^{* * *} \\
(0.223) \\
\end{array}$ & $\begin{array}{l}-12.349^{* * *} \\
(0.239) \\
\end{array}$ & $\begin{array}{l}-12.948^{* * *} \\
(0.162) \\
\end{array}$ & $\begin{array}{l}-13.240^{* * * *} \\
(0.213)\end{array}$ \\
\hline $\mathrm{R}^{2}$ & 0.241 & 0.195 & 0.171 & 0.159 & 0.240 & 0.183 & 0.170 & 0.202 \\
\hline $\mathrm{F}$ & $28.56^{* * *}$ & $22.00^{* * * *}$ & $18.99^{* * *}$ & $17.49^{* * *}$ & $28.40^{* * *}$ & $20.48^{* * *}$ & $18.82^{* * *}$ & $22.95^{* * *}$ \\
\hline
\end{tabular}

Table 4: Filmgoing, Rock, Jazz or Classical music demand, estimation results, SUR method, ${ }^{* * *},{ }^{* *},, 0$ denote 0.1 $\%, 1 \%, 5 \%$ or $10 \%$ statistical significance, standard errors in parenthesis. $\mathrm{N}=1388$. Note: a negative sign indicates a positive influence 


\begin{tabular}{|c|c|c|c|c|c|c|c|c|}
\hline & Museum & Opera & Theatre & Musicals & Museum & Opera & Theatre & Musicals \\
\hline $\log w$ & $\begin{array}{l}-0.357^{* * *} \\
(0.050)\end{array}$ & $\begin{array}{l}-0.358^{* * *} \\
(0.031)\end{array}$ & $\begin{array}{l}-0.270^{* * *} \\
(0.039)\end{array}$ & $\begin{array}{l}0.354^{* * *} \\
(0.033)\end{array}$ & $\begin{array}{l}-0.356^{* * *} \\
(0.049)\end{array}$ & $\begin{array}{l}-0.358^{* * *} \\
(0.030)\end{array}$ & $\begin{array}{l}-0.275^{* * *} \\
(0.039)\end{array}$ & $\begin{array}{l}-0.357^{* * *} \\
(0.033)\end{array}$ \\
\hline $\begin{array}{l}\text { Vocational } \\
\text { education }\end{array}$ & $\begin{array}{l}0.096 \\
(0.167) \\
\end{array}$ & $\begin{array}{l}-0.046 \\
(0.104) \\
\end{array}$ & $\begin{array}{l}0.246^{(*)} \\
(0.130)\end{array}$ & $\begin{array}{l}-0.097 \\
(0.111) \\
\end{array}$ & $\begin{array}{l}0.121 \\
(0.164) \\
\end{array}$ & $\begin{array}{l}-0.025 \\
(0.102)\end{array}$ & $\begin{array}{l}0.260^{*} \\
(0.130) \\
\end{array}$ & $\begin{array}{l}-0.091 \\
(0.111)\end{array}$ \\
\hline College & $\begin{array}{l}0.402^{*} \\
(0.179) \\
\end{array}$ & $\begin{array}{l}0.114 \\
(0.112) \\
\end{array}$ & $\begin{array}{l}0.504^{* * *} \\
(0.140)\end{array}$ & $\begin{array}{l}-0.195 \\
(0.119) \\
\end{array}$ & $\begin{array}{l}0.402^{*} \\
(0.176) \\
\end{array}$ & $\begin{array}{l}0.118 \\
(0.109) \\
\end{array}$ & $\begin{array}{l}0.515^{* * *} \\
(0.140)\end{array}$ & $\begin{array}{l}-0.187 \\
(0.119) \\
\end{array}$ \\
\hline Bachelor & $\begin{array}{l}0.664^{* *} \\
(0.229)\end{array}$ & $\begin{array}{l}0.355^{*} \\
(0.143)\end{array}$ & $\begin{array}{l}0.695^{* * * *} \\
(0.179)\end{array}$ & $\begin{array}{l}-0.210 \\
(0.152)\end{array}$ & $\begin{array}{l}0.551^{*} \\
(0.226)\end{array}$ & $\begin{array}{l}0.274^{(*)} \\
(0.140)\end{array}$ & $\begin{array}{l}0.672^{* * *} \\
(0.180)\end{array}$ & $\begin{array}{l}-0.213 \\
(0.153)\end{array}$ \\
\hline Master & $\begin{array}{l}1.610^{* * * *} \\
(0.193)\end{array}$ & $\begin{array}{l}0.914^{* * * *} \\
(0.121)\end{array}$ & $\begin{array}{l}1.012^{* * * *} \\
(0.151)\end{array}$ & $\begin{array}{l}-0.020 \\
(0.128)\end{array}$ & $\begin{array}{l}1.429^{* * * *} \\
(0.191)\end{array}$ & $\begin{array}{l}0.776^{* * *} \\
(0.119)\end{array}$ & $\begin{array}{l}0.951^{* * * *} \\
(0.152)\end{array}$ & $\begin{array}{l}-0.048 \\
(0.129)\end{array}$ \\
\hline Doctor & $\begin{array}{l}1.792^{* * * *} \\
(0.398)\end{array}$ & $\begin{array}{l}0.880^{* * * *} \\
(0.249)\end{array}$ & $\begin{array}{l}0.716^{*} \\
(0.312)\end{array}$ & $\begin{array}{l}0.010 \\
(0.265)\end{array}$ & $\begin{array}{l}1.610^{* * * *} \\
(0.392)\end{array}$ & $\begin{array}{l}0.735^{* *} \\
(0.244)\end{array}$ & $\begin{array}{l}0.625^{*} \\
(0.312)\end{array}$ & $\begin{array}{l}-0.037 \\
(0.266)\end{array}$ \\
\hline Female & $\begin{array}{l}0.370^{* * *} \\
(0.113)\end{array}$ & $\begin{array}{l}0.508^{* * * *} \\
(0.071)\end{array}$ & $\begin{array}{l}0.889^{* * *} \\
(0.089)\end{array}$ & $\begin{array}{l}0.502^{* * * *} \\
(0.075)\end{array}$ & $\begin{array}{l}0.362^{* * *} \\
(0.111)\end{array}$ & $\begin{array}{l}0.504^{* * * *} \\
(0.069)\end{array}$ & $\begin{array}{l}0.899^{* * * *} \\
(0.088)\end{array}$ & $\begin{array}{l}0.512^{* * * *} \\
(0.075)\end{array}$ \\
\hline Age $15-24$ & $\begin{array}{l}0.516^{*} \\
(0.223)\end{array}$ & $\begin{array}{l}0.385^{* * *} \\
(0.140)\end{array}$ & $\begin{array}{l}0.489^{* * *} \\
(0.175)\end{array}$ & $\begin{array}{l}0.648^{* * * *} \\
(0.148)\end{array}$ & $\begin{array}{l}0.514^{*} \\
(0.220)\end{array}$ & $\begin{array}{l}0.395^{* *} \\
(0.136)\end{array}$ & $\begin{array}{l}0.513^{* *} \\
(0.175)\end{array}$ & $\begin{array}{l}0.671^{* * * *} \\
(0.149)\end{array}$ \\
\hline Age $25-34$ & $\begin{array}{l}-0.068 \\
(0.195) \\
\end{array}$ & $\begin{array}{l}-0.089 \\
(0.122) \\
\end{array}$ & $\begin{array}{l}-0.290^{(*)} \\
(0.153) \\
\end{array}$ & $\begin{array}{l}0.042 \\
(0.130) \\
\end{array}$ & $\begin{array}{l}-0.025 \\
(0.191) \\
\end{array}$ & $\begin{array}{l}-0.050 \\
(0.119) \\
\end{array}$ & $\begin{array}{l}-0.262^{(*)} \\
(0.152) \\
\end{array}$ & $\begin{array}{l}0.067 \\
(0.129) \\
\end{array}$ \\
\hline Age $45-54$ & $\begin{array}{l}0.155 \\
(0.185)\end{array}$ & $\begin{array}{l}0.141 \\
(0.116)\end{array}$ & $\begin{array}{l}0.348^{*} \\
(0.145)\end{array}$ & $\begin{array}{l}0.134 \\
(0.123)\end{array}$ & $\begin{array}{l}0.157 \\
(0.181)\end{array}$ & $\begin{array}{l}0.141 \\
(0.113)\end{array}$ & $\begin{array}{l}0.336^{*} \\
(0.144)\end{array}$ & $\begin{array}{l}0.126 \\
(0.123)\end{array}$ \\
\hline Age $55-64$ & $\begin{array}{l}0.498^{* *} \\
(0.180)\end{array}$ & $\begin{array}{l}0.599^{* * * *} \\
(0.113)\end{array}$ & $\begin{array}{l}0.756^{* * * *} \\
(0.141)\end{array}$ & $\begin{array}{l}0.568^{* * * *} \\
(0.120)\end{array}$ & $\begin{array}{l}0.493^{* *} \\
(0.177)\end{array}$ & $\begin{array}{l}0.588^{* * *} \\
(0.110)\end{array}$ & $\begin{array}{l}0.723^{* * *} \\
(0.141)\end{array}$ & $\begin{array}{l}0.540^{* * *} \\
(0.120)\end{array}$ \\
\hline Age 65 - & $\begin{array}{l}1.701^{* * * *} \\
(0.234)\end{array}$ & $\begin{array}{l}1.710^{* * * *} \\
(0.146)\end{array}$ & $\begin{array}{l}1.633^{* * * *} \\
(0.183)\end{array}$ & $\begin{array}{l}1.800^{* * * *} \\
(0.156)\end{array}$ & $\begin{array}{l}1.661^{* * *} \\
(0.229)\end{array}$ & $\begin{array}{l}1.669^{* * * *} \\
(0.142)\end{array}$ & $\begin{array}{l}1.581^{* * *} \\
(0.182)\end{array}$ & $\begin{array}{l}1.758^{* * * *} \\
(0.155)\end{array}$ \\
\hline \multicolumn{9}{|l|}{$\begin{array}{l}\text { Father: Reading } \\
\text { interested }\end{array}$} \\
\hline \multicolumn{9}{|l|}{$\begin{array}{l}\text { Mother: Reading } \\
\text { interested }\end{array}$} \\
\hline $\begin{array}{l}\text { Father: Filmgoing } \\
\text { interested }\end{array}$ & $\begin{array}{l}0.044 \\
(0.140) \\
\end{array}$ & $\begin{array}{l}0.066 \\
(0.088) \\
\end{array}$ & $\begin{array}{l}0.113 \\
(0.110) \\
\end{array}$ & $\begin{array}{l}0.268^{* *} \\
(0.093) \\
\end{array}$ & $\begin{array}{l}-0.033 \\
(0.137) \\
\end{array}$ & $\begin{array}{l}0.013 \\
(0.085) \\
\end{array}$ & $\begin{array}{l}0.109 \\
(0.109)\end{array}$ & $\begin{array}{l}0.284^{* *} \\
(0.093)\end{array}$ \\
\hline $\begin{array}{l}\text { Mother: } \\
\text { Filmgoing } \\
\text { interested }\end{array}$ & $\begin{array}{l}0.117 \\
(0.146)\end{array}$ & $\begin{array}{l}0.170^{(*)} \\
(0.091)\end{array}$ & $\begin{array}{l}0.257^{*} \\
(0.114)\end{array}$ & $\begin{array}{l}-0.048 \\
(0.097)\end{array}$ & $\begin{array}{l}0.099 \\
(0.142)\end{array}$ & $\begin{array}{l}0.169^{(*)} \\
(0.088)\end{array}$ & $\begin{array}{l}0.304^{* *} \\
(0.113)\end{array}$ & $\begin{array}{l}-0.009 \\
(0.096)\end{array}$ \\
\hline $\begin{array}{l}\text { Father: Pop music } \\
\text { interested }\end{array}$ & $\begin{array}{l}0.258 \\
(0.165)\end{array}$ & $\begin{array}{l}0.226^{*} \\
(0.103)\end{array}$ & $\begin{array}{l}0.116 \\
(0.129)\end{array}$ & $\begin{array}{l}0.122 \\
(0.110)\end{array}$ & & & & \\
\hline $\begin{array}{l}\text { Mother: Pop } \\
\text { music interested }\end{array}$ & $\begin{array}{l}-0.014 \\
(0.162)\end{array}$ & $\begin{array}{l}0.048 \\
(0.101)\end{array}$ & $\begin{array}{l}0.303^{*} \\
(0.127)\end{array}$ & $\begin{array}{l}0.217^{*} \\
(0.108)\end{array}$ & & & & \\
\hline $\begin{array}{l}\text { Father: Classical } \\
\text { music interested }\end{array}$ & & & & & $\begin{array}{l}0.652^{* * *} \\
(0.192)\end{array}$ & $\begin{array}{l}0.587^{* * *} \\
(0.119)\end{array}$ & $\begin{array}{l}0.332^{*} \\
(0.153)\end{array}$ & $\begin{array}{l}0.193 \\
(0.130)\end{array}$ \\
\hline $\begin{array}{l}\text { Mother: Classical } \\
\text { music interested }\end{array}$ & & & & & $\begin{array}{l}0.860^{* * * *} \\
(0.185)\end{array}$ & $\begin{array}{l}0.582^{* * * *} \\
(0.115)\end{array}$ & $\begin{array}{l}0.231 \\
(0.147)\end{array}$ & $\begin{array}{l}0.050 \\
(0.125)\end{array}$ \\
\hline \multicolumn{9}{|l|}{$\begin{array}{l}\text { Father: Visual } \\
\text { arts interested }\end{array}$} \\
\hline \multicolumn{9}{|l|}{$\begin{array}{l}\text { Mother: Visual } \\
\text { arts interested }\end{array}$} \\
\hline \multicolumn{9}{|l|}{$\begin{array}{ll}\begin{array}{l}\text { Father: } \\
\text { interested }\end{array} & \text { Sports } \\
\end{array}$} \\
\hline \multicolumn{9}{|l|}{$\begin{array}{ll}\text { Mother: } & \text { Sports } \\
\text { interested } & \end{array}$} \\
\hline constant & $\begin{array}{l}-12.992^{* * * *} \\
(0.291)\end{array}$ & $\begin{array}{l}-13.265^{* * *} \\
(0.182)\end{array}$ & $\begin{array}{l}-12.314^{* * * *} \\
(0.228)\end{array}$ & $\begin{array}{l}-13.445^{* * * *} \\
(0.194)\end{array}$ & $\begin{array}{l}-13.051^{* * *} \\
(0.285)\end{array}$ & $\begin{array}{l}-13.298^{* * *} \\
(0.177)\end{array}$ & $\begin{array}{l}-12.274^{* * *} \\
(0.227)\end{array}$ & $\begin{array}{l}-13.405^{* * * *} \\
(0.193)\end{array}$ \\
\hline $\mathrm{R}^{2}$ & 0.094 & 0.172 & 0.152 & 0.144 & 0.124 & 0.210 & 0.153 & 0.140 \\
\hline $\mathrm{F}$ & $10.10^{* * *}$ & $19.01^{* * *}$ & $16.61^{* * *}$ & $15.59^{* * *}$ & $13.32^{* * *}$ & $24.14^{* * *}$ & $16.68^{* * *}$ & $15.21^{* * *}$ \\
\hline
\end{tabular}

Table 5: Museum, Opera, Theatre or Musical demand, estimation results, SUR method, ${ }^{* * *},{ }^{* *},, 0$ denote $0.1 \%, 1$

$\%, 5 \%$ or $10 \%$ statistical significance, standard errors in parenthesis. $\mathrm{N}=1388$. Note: a negative sign indicates a positive influence 


\begin{tabular}{|c|c|c|c|c|c|c|c|c|}
\hline & Art gallery & Sport & Art gallery & Sport & Art gallery & Sport & Art gallery & Sport \\
\hline $\log w$ & $\begin{array}{l}-0.383^{* * *} \\
(0.047)\end{array}$ & $\begin{array}{l}-0.377^{* * *} \\
(0.051)\end{array}$ & $\begin{array}{l}-0.383^{* * *} \\
(0.046)\end{array}$ & $\begin{array}{l}-0.380^{* * *} \\
(0.051)\end{array}$ & $\begin{array}{l}-0.382^{* * *} \\
(0.047)\end{array}$ & $\begin{array}{l}-0.392^{* * *} \\
(0.028)\end{array}$ & $\begin{array}{l}-0.382^{* * *} \\
(0.046)\end{array}$ & $\begin{array}{l}-0.394^{* * *} \\
(0.028)\end{array}$ \\
\hline $\begin{array}{l}\text { Vocational } \\
\text { education }\end{array}$ & $\begin{array}{l}-0.199 \\
(0.156)\end{array}$ & $\begin{array}{l}-0.286^{(*)} \\
(0.169)\end{array}$ & $\begin{array}{l}-0.172 \\
(0.153)\end{array}$ & $\begin{array}{l}-0.281^{(*)} \\
(0.170)\end{array}$ & $\begin{array}{l}-0.199 \\
(0.156)\end{array}$ & $\begin{array}{l}-0.286^{* *} \\
(0.096)\end{array}$ & $\begin{array}{l}-0.172 \\
(0.153)\end{array}$ & $\begin{array}{l}-0.282^{* *} \\
(0.096)\end{array}$ \\
\hline College & $\begin{array}{l}0.308^{(*)} \\
(0.168)\end{array}$ & $\begin{array}{l}0.126 \\
(0.182)\end{array}$ & $\begin{array}{l}0.316^{(*)} \\
(0.165)\end{array}$ & $\begin{array}{l}0.131 \\
(0.182)\end{array}$ & $\begin{array}{l}0.308^{(*)} \\
(0.168)\end{array}$ & $\begin{array}{l}0.128 \\
(0.103)\end{array}$ & $\begin{array}{l}0.316^{(*)} \\
(0.165)\end{array}$ & $\begin{array}{l}0.130 \\
(0.103)\end{array}$ \\
\hline Bachelor & $\begin{array}{l}0.565^{* *} \\
(0.215)\end{array}$ & $\begin{array}{l}0.249 \\
(0.233)\end{array}$ & $\begin{array}{l}0.459^{*} \\
(0.211)\end{array}$ & $\begin{array}{l}0.246 \\
(0.234)\end{array}$ & $\begin{array}{l}0.565^{* *} \\
(0.215)\end{array}$ & $\begin{array}{l}0.240^{(*)} \\
(0.132)\end{array}$ & $\begin{array}{l}0.459^{*} \\
(0.211)\end{array}$ & $\begin{array}{l}0.237^{(*)} \\
(0.132)\end{array}$ \\
\hline Master & $\begin{array}{l}1.375^{* * * *} \\
(0.181)\end{array}$ & $\begin{array}{l}0.448^{*} \\
(0.196)\end{array}$ & $\begin{array}{l}1.215^{* * *} \\
(0.179)\end{array}$ & $\begin{array}{l}0.413^{*} \\
(0.198)\end{array}$ & $\begin{array}{l}1.375^{\text {*** }} \\
(0.181)\end{array}$ & $\begin{array}{l}0.456^{* * * *} \\
(0.111)\end{array}$ & $\begin{array}{l}1.214^{* * *} \\
(0.179)\end{array}$ & $\begin{array}{l}0.433^{* * * *} \\
(0.112)\end{array}$ \\
\hline Doctor & $\begin{array}{l}1.334^{* * * *} \\
(0.373)\end{array}$ & $\begin{array}{l}0.192 \\
(0.405)\end{array}$ & $\begin{array}{l}1.170^{* * *} \\
(0.367)\end{array}$ & $\begin{array}{l}0.137 \\
(0.406)\end{array}$ & $\begin{array}{l}1.334^{* * * *} \\
(0.373)\end{array}$ & $\begin{array}{l}0.202 \\
(0.229)\end{array}$ & $\begin{array}{l}1.169^{* * *} \\
(0.367)\end{array}$ & $\begin{array}{l}0.166 \\
(0.230)\end{array}$ \\
\hline Female & $\begin{array}{l}0.386^{* * * *} \\
(0.106)\end{array}$ & $\begin{array}{l}0.602^{* * * *} \\
(0.115)\end{array}$ & $\begin{array}{l}0.371^{* * * *} \\
(0.104)\end{array}$ & $\begin{array}{l}0.617^{* * * *} \\
(0.115)\end{array}$ & $\begin{array}{l}0.386^{* * *} \\
(0.106)\end{array}$ & $\begin{array}{l}0.612^{* * *} \\
(0.065)\end{array}$ & $\begin{array}{l}0.371^{* * *} \\
(0.104)\end{array}$ & $\begin{array}{l}0.621^{* * *} \\
(0.065)\end{array}$ \\
\hline Age $15-24$ & $\begin{array}{l}0.641^{* *} \\
(0.209)\end{array}$ & $\begin{array}{l}0.988^{* * * *} \\
(0.227)\end{array}$ & $\begin{array}{l}0.647^{* *} \\
(0.206)\end{array}$ & $\begin{array}{l}1.008^{* * * *} \\
(0.227)\end{array}$ & $\begin{array}{l}0.641^{* *} \\
(0.209)\end{array}$ & $\begin{array}{l}0.986^{* * * *} \\
(0.128)\end{array}$ & $\begin{array}{l}0.647^{* *} \\
(0.205)\end{array}$ & $\begin{array}{l}0.996^{* * *} \\
(0.129)\end{array}$ \\
\hline Age $25-34$ & $\begin{array}{l}-0.060 \\
(0.183) \\
\end{array}$ & $\begin{array}{l}0.002 \\
(0.199)\end{array}$ & $\begin{array}{l}-0.035 \\
(0.179)\end{array}$ & $\begin{array}{l}0.034 \\
(0.198)\end{array}$ & $\begin{array}{l}-0.060 \\
(0.183)\end{array}$ & $\begin{array}{l}-0.004 \\
(0.112)\end{array}$ & $\begin{array}{l}-0.034 \\
(0.179)\end{array}$ & $\begin{array}{l}0.014 \\
(0.112)\end{array}$ \\
\hline Age $45-54$ & $\begin{array}{l}0.350^{*} \\
(0.173)\end{array}$ & $\begin{array}{l}0.063 \\
(0.188)\end{array}$ & $\begin{array}{l}0.355^{*} \\
(0.170)\end{array}$ & $\begin{array}{l}0.053 \\
(0.188)\end{array}$ & $\begin{array}{l}0.350^{*} \\
(0.173)\end{array}$ & $\begin{array}{l}0.050 \\
(0.106)\end{array}$ & $\begin{array}{l}0.356^{*} \\
(0.170)\end{array}$ & $\begin{array}{l}0.043 \\
(0.106)\end{array}$ \\
\hline Age 55-64 & $\begin{array}{l}0.831^{* * * *} \\
(0.169)\end{array}$ & $\begin{array}{l}0.165 \\
(0.183)\end{array}$ & $\begin{array}{l}0.839^{* * *} \\
(0.166)\end{array}$ & $\begin{array}{l}0.130 \\
(0.183)\end{array}$ & $\begin{array}{l}0.832^{* * *} \\
(0.169)\end{array}$ & $\begin{array}{l}0.136 \\
(0.104)\end{array}$ & $\begin{array}{l}0.839^{* * *} \\
(0.165)\end{array}$ & $\begin{array}{l}0.113 \\
(0.104)\end{array}$ \\
\hline Age 65 - & $\begin{array}{l}1.818^{* * *} \\
(0.219)\end{array}$ & $\begin{array}{l}1.209^{* * * *} \\
(0.238)\end{array}$ & $\begin{array}{l}1.801^{* * * *} \\
(0.214)\end{array}$ & $\begin{array}{l}1.155^{\text {**** }} \\
(0.237)\end{array}$ & $\begin{array}{l}1.818^{* * *} \\
(0.219)\end{array}$ & $\begin{array}{l}1.201^{* * * *} \\
(0.135)\end{array}$ & $\begin{array}{l}1.801^{* * *} \\
(0.214)\end{array}$ & $\begin{array}{l}1.167^{* * * *} \\
(0.134)\end{array}$ \\
\hline \multicolumn{9}{|l|}{$\begin{array}{l}\text { Father: Reading } \\
\text { interested }\end{array}$} \\
\hline \multicolumn{9}{|l|}{$\begin{array}{l}\text { Mother: Reading } \\
\text { interested }\end{array}$} \\
\hline $\begin{array}{l}\text { Father: Filmgoing } \\
\text { interested }\end{array}$ & $\begin{array}{l}-0.011 \\
(0.131)\end{array}$ & $\begin{array}{l}0.092 \\
(0.142)\end{array}$ & $\begin{array}{l}-0.113 \\
(0.128)\end{array}$ & $\begin{array}{l}0.121 \\
(0.142)\end{array}$ & $\begin{array}{l}-0.011 \\
(0.131)\end{array}$ & $\begin{array}{l}0.088 \\
(0.080)\end{array}$ & $\begin{array}{l}-0.112 \\
(0.128)\end{array}$ & $\begin{array}{l}0.106 \\
(0.080)\end{array}$ \\
\hline $\begin{array}{l}\text { Mother: } \\
\text { Filmgoing } \\
\text { interested }\end{array}$ & $\begin{array}{l}0.290^{*} \\
(0.137)\end{array}$ & $\begin{array}{l}0.147 \\
(0.149)\end{array}$ & $\begin{array}{l}0.267^{*} \\
(0.133)\end{array}$ & $\begin{array}{l}0.191 \\
(0.147)\end{array}$ & $\begin{array}{l}0.294^{*} \\
(0.137)\end{array}$ & $\begin{array}{l}0.014 \\
(0.084)\end{array}$ & $\begin{array}{l}0.273^{*} \\
(0.133)\end{array}$ & $\begin{array}{l}0.041 \\
(0.083)\end{array}$ \\
\hline $\begin{array}{l}\text { Father: Pop music } \\
\text { interested }\end{array}$ & $\begin{array}{l}0.115 \\
(0.155)\end{array}$ & $\begin{array}{l}0.185 \\
(0.168)\end{array}$ & & & $\begin{array}{l}0.117 \\
(0.154)\end{array}$ & $\begin{array}{l}0.111 \\
(0.095)\end{array}$ & & \\
\hline $\begin{array}{l}\text { Mother: Pop } \\
\text { music interested }\end{array}$ & $\begin{array}{l}-0.044 \\
(0.152)\end{array}$ & $\begin{array}{l}0.252 \\
(0.165)\end{array}$ & & & $\begin{array}{l}-0.041 \\
(0.152)\end{array}$ & $\begin{array}{l}0.163^{(*)} \\
(0.093)\end{array}$ & & \\
\hline $\begin{array}{l}\text { Father: Classical } \\
\text { music interested }\end{array}$ & & & $\begin{array}{l}0.810^{* * *} \\
(0.180)\end{array}$ & $\begin{array}{l}0.105 \\
(0.199)\end{array}$ & & & $\begin{array}{l}0.812^{* * *} \\
(0.180)\end{array}$ & $\begin{array}{l}0.034 \\
(0.113)\end{array}$ \\
\hline $\begin{array}{l}\text { Mother: Classical } \\
\text { music interested }\end{array}$ & & & $\begin{array}{l}0.642^{* * *} \\
(0.173)\end{array}$ & $\begin{array}{l}0.143 \\
(0.192)\end{array}$ & & & $\begin{array}{l}0.642^{* * * *} \\
(0.173)\end{array}$ & $\begin{array}{l}0.127 \\
(0.108)\end{array}$ \\
\hline \multicolumn{9}{|l|}{$\begin{array}{l}\text { Father: Visual } \\
\text { arts interested }\end{array}$} \\
\hline \multicolumn{9}{|l|}{$\begin{array}{l}\text { Mother: Visual } \\
\text { arts interested }\end{array}$} \\
\hline \multicolumn{9}{|l|}{$\begin{array}{ll}\text { Father: } & \text { Sports } \\
\text { interested } & \end{array}$} \\
\hline \multicolumn{9}{|l|}{$\begin{array}{ll}\text { Mother: Sports } \\
\text { interested }\end{array}$} \\
\hline Mills ratio (sport) & & & & & $\begin{array}{l}-0.088 \\
(0.075)\end{array}$ & $\begin{array}{l}2.530^{* * *} \\
(0.046)\end{array}$ & $\begin{array}{l}-0.095 \\
(0.074)\end{array}$ & $\begin{array}{l}2.533^{\text {**** }} \\
(0.046)\end{array}$ \\
\hline constant & $\begin{array}{l}-13.142^{* * *} \\
(0.273)\end{array}$ & $\begin{array}{l}-7.369^{\text {**** }} \\
(0.296)\end{array}$ & $\begin{array}{l}-13.221^{* * * *} \\
(0.267)\end{array}$ & $\begin{array}{l}-7.315^{* * * *} \\
(0.296)\end{array}$ & $\begin{array}{l}-13.147^{* * *} \\
(0.273)\end{array}$ & $\begin{array}{l}-7.236^{* * *} \\
(0.168)\end{array}$ & $\begin{array}{l}-13.225^{* * *} \\
(0.267)\end{array}$ & $\begin{array}{l}-7.201^{* * *} \\
(0.167)\end{array}$ \\
\hline $\mathrm{R}^{2}$ & 0.111 & 0.077 & 0.142 & 0.074 & 0.111 & 0.703 & 0.142 & 0.702 \\
\hline $\mathrm{F}$ & $11.84^{* * *}$ & $8.25^{* * *}$ & $15.41^{* * *}$ & $7.94^{* * *}$ & $11.23^{* * *}$ & $194.49^{* * * *}$ & $14.60^{* * *}$ & $193.44^{* * * *}$ \\
\hline
\end{tabular}

Table 6: Art gallery or sport demand, estimation results, SURE method, ${ }^{* * *},{ }^{* *},{ }^{0}$ denote $0.1 \%, 1 \%, 5 \%$ or $10 \%$ statistical significance, standard errors in parenthesis. $N=1388$. Note: a negative sign indicates a positive influence 


\begin{tabular}{|c|c|c|c|c|c|c|c|c|c|c|}
\hline & Filmgoing & $\begin{array}{l}\text { Rock } \\
\text { music }\end{array}$ & $\begin{array}{l}\text { Jazz } \\
\text { music }\end{array}$ & $\begin{array}{l}\text { Classical } \\
\text { music }\end{array}$ & Museum & Opera & Theatre & Musicals & $\begin{array}{l}\text { Art } \\
\text { Gallery }\end{array}$ & Sport \\
\hline $\begin{array}{l}\text { Father: } \\
\text { Reading } \\
\text { interested }\end{array}$ & $\begin{array}{l}0.071 \\
(0.088)\end{array}$ & $\begin{array}{l}-0.089 \\
(0.094)\end{array}$ & $\begin{array}{l}0.013 \\
(0.064)\end{array}$ & $\begin{array}{l}0.142^{(*)} \\
(0.086)\end{array}$ & $\begin{array}{l}0.138 \\
(0.114)\end{array}$ & $\begin{array}{l}0.093 \\
(0.072)\end{array}$ & $\begin{array}{l}0.025 \\
(0.089)\end{array}$ & $\begin{array}{l}0.111 \\
(0.076)\end{array}$ & $\begin{array}{l}0.245^{*} \\
(0.106)\end{array}$ & $\begin{array}{l}0.018 \\
(0.116)\end{array}$ \\
\hline $\begin{array}{l}\text { Mother: } \\
\text { Reading } \\
\text { interested }\end{array}$ & $\begin{array}{l}0.268^{* *} \\
(0.089)\end{array}$ & $\begin{array}{l}0.191^{*} \\
(0.095)\end{array}$ & $\begin{array}{l}0.068 \\
(0.065)\end{array}$ & $\begin{array}{l}0.228^{* *} \\
(0.087)\end{array}$ & $\begin{array}{l}0.375^{* *} \\
(0.115)\end{array}$ & $\begin{array}{l}0.127^{(*)} \\
(0.072)\end{array}$ & $\begin{array}{l}0.365^{* * *} \\
(0.090)\end{array}$ & $\begin{array}{l}-0.009 \\
(0.077)\end{array}$ & $\begin{array}{l}0.450^{* * *} \\
(0.107)\end{array}$ & $\begin{array}{l}0.123 \\
(0.118)\end{array}$ \\
\hline $\begin{array}{l}\text { Father: } \\
\text { Filmgoing } \\
\text { interested }\end{array}$ & $\begin{array}{l}0.229^{*} \\
(0.107)\end{array}$ & $\begin{array}{l}-0.002 \\
(0.115)\end{array}$ & $\begin{array}{l}0.035 \\
(0.078)\end{array}$ & $\begin{array}{l}0.040 \\
(0.106)\end{array}$ & $\begin{array}{l}0.044 \\
(0.140)\end{array}$ & $\begin{array}{l}0.066 \\
(0.088)\end{array}$ & $\begin{array}{l}0.113 \\
(0.110)\end{array}$ & $\begin{array}{l}0.268^{* *} \\
(0.093)\end{array}$ & $\begin{array}{l}-0.011 \\
(0.131)\end{array}$ & $\begin{array}{l}0.092 \\
(0.142)\end{array}$ \\
\hline $\begin{array}{l}\text { Mother: } \\
\text { Filmgoing } \\
\text { interested }\end{array}$ & $\begin{array}{l}0.268^{*} \\
(0.112)\end{array}$ & $\begin{array}{l}0.054 \\
(0.120)\end{array}$ & $\begin{array}{l}0.003 \\
(0.081)\end{array}$ & $\begin{array}{l}0.139 \\
(0.110)\end{array}$ & $\begin{array}{l}0.117 \\
(0.146)\end{array}$ & $\begin{array}{l}0.170^{(*)} \\
(0.091)\end{array}$ & $\begin{array}{l}0.257^{*} \\
(0.114)\end{array}$ & $\begin{array}{l}-0.048 \\
(0.097)\end{array}$ & $\begin{array}{l}0.290^{*} \\
(0.137)\end{array}$ & $\begin{array}{l}0.147 \\
(0.149)\end{array}$ \\
\hline $\begin{array}{l}\text { Father: } \\
\text { Pop music } \\
\text { interested }\end{array}$ & $\begin{array}{l}0.199 \\
(0.127)\end{array}$ & $\begin{array}{l}0.353^{* *} \\
(0.135)\end{array}$ & $\begin{array}{l}0.135 \\
(0.092)\end{array}$ & $\begin{array}{l}0.321^{* *} \\
(0.124)\end{array}$ & $\begin{array}{l}0.258 \\
(0.165)\end{array}$ & $\begin{array}{l}0.226^{*} \\
(0.103)\end{array}$ & $\begin{array}{l}0.116 \\
(0.129)\end{array}$ & $\begin{array}{l}0.122 \\
(0.110)\end{array}$ & $\begin{array}{l}0.115 \\
(0.155)\end{array}$ & $\begin{array}{l}0.185 \\
(0.168)\end{array}$ \\
\hline $\begin{array}{l}\text { Mother: } \\
\text { Pop music } \\
\text { interested }\end{array}$ & $\begin{array}{l}0.315^{*} \\
(0.124)\end{array}$ & $\begin{array}{l}0.333^{*} \\
(0.133)\end{array}$ & $\begin{array}{l}0.243^{* *} \\
(0.090)\end{array}$ & $\begin{array}{l}0.157 \\
(0.122)\end{array}$ & $\begin{array}{l}-0.014 \\
(0.162)\end{array}$ & $\begin{array}{l}0.048 \\
(0.101)\end{array}$ & $\begin{array}{l}0.303^{*} \\
(0.127)\end{array}$ & $\begin{array}{l}0.217^{*} \\
(0.108)\end{array}$ & $\begin{array}{l}-0.044 \\
(0.152)\end{array}$ & $\begin{array}{l}0.252 \\
(0.165)\end{array}$ \\
\hline $\begin{array}{l}\text { Father: } \\
\text { Classical } \\
\text { music } \\
\text { interested }\end{array}$ & $\begin{array}{l}0.086 \\
(0.150)\end{array}$ & $\begin{array}{l}0.208 \\
(0.161)\end{array}$ & $\begin{array}{l}0.172 \\
(0.109)\end{array}$ & $\begin{array}{l}0.565^{* * *} \\
(0.144)\end{array}$ & $\begin{array}{l}0.652^{* * *} \\
(0.192)\end{array}$ & $\begin{array}{l}0.587^{* * *} \\
(0.119)\end{array}$ & $\begin{array}{l}0.332^{*} \\
(0.153)\end{array}$ & $\begin{array}{l}0.193 \\
(0.130)\end{array}$ & $\begin{array}{l}0.810^{* * *} \\
(0.180)\end{array}$ & $\begin{array}{l}0.105 \\
(0.199)\end{array}$ \\
\hline $\begin{array}{l}\text { Mother: } \\
\text { Classical } \\
\text { music } \\
\text { interested }\end{array}$ & $\begin{array}{l}0.443^{* *} \\
(0.144)\end{array}$ & $\begin{array}{l}0.010 \\
(0.155)\end{array}$ & $\begin{array}{l}0.258^{*} \\
(0.105)\end{array}$ & $\begin{array}{l}0.916^{* * *} \\
(0.138)\end{array}$ & $\begin{array}{l}0.860^{* * *} \\
(0.185)\end{array}$ & $\begin{array}{l}0.582^{* * *} \\
(0.115)\end{array}$ & $\begin{array}{l}0.231 \\
(0.147)\end{array}$ & $\begin{array}{l}0.050 \\
(0.125)\end{array}$ & $\begin{array}{l}0.642^{* * *} \\
(0.173)\end{array}$ & $\begin{array}{l}0.143 \\
(0.192)\end{array}$ \\
\hline $\begin{array}{l}\text { Father: } \\
\text { Visual } \\
\text { arts } \\
\text { interested }\end{array}$ & $\begin{array}{l}0.118 \\
(0.168)\end{array}$ & $\begin{array}{l}0.137 \\
(0.181)\end{array}$ & $\begin{array}{l}-0.023 \\
(0.123)\end{array}$ & $\begin{array}{l}0.257 \\
(0.165)\end{array}$ & $\begin{array}{l}0.451^{*} \\
(0.217)\end{array}$ & $\begin{array}{l}0.120 \\
(0.136)\end{array}$ & $\begin{array}{l}0.256 \\
(0.172)\end{array}$ & $\begin{array}{l}0.155 \\
(0.146)\end{array}$ & $\begin{array}{l}0.762^{* * *} \\
(0.201)\end{array}$ & $\begin{array}{l}-0.471^{*} \\
(0.223)\end{array}$ \\
\hline $\begin{array}{l}\text { Mother: } \\
\text { Visual } \\
\text { arts } \\
\text { interested }\end{array}$ & $\begin{array}{l}0.371^{* *} \\
(0.129)\end{array}$ & $\begin{array}{l}-0.161 \\
(0.139)\end{array}$ & $\begin{array}{l}0.078 \\
(0.094)\end{array}$ & $\begin{array}{l}0.491^{* * *} \\
(0.127)\end{array}$ & $\begin{array}{l}0.781^{* * *} \\
(0.167)\end{array}$ & $\begin{array}{l}0.451^{* * *} \\
(0.105)\end{array}$ & $\begin{array}{l}0.087 \\
(0.132)\end{array}$ & $\begin{array}{l}0.041 \\
(0.112)\end{array}$ & $\begin{array}{l}0.812^{* * *} \\
(0.155)\end{array}$ & $\begin{array}{l}-0.018 \\
(0.171)\end{array}$ \\
\hline $\begin{array}{l}\text { Father: } \\
\text { Sports } \\
\text { interested }\end{array}$ & $\begin{array}{l}0.185^{*} \\
(0.090)\end{array}$ & $\begin{array}{l}0.172^{(*)} \\
(0.096)\end{array}$ & $\begin{array}{l}0.061 \\
(0.065)\end{array}$ & $\begin{array}{l}0.133 \\
(0.088)\end{array}$ & $\begin{array}{l}0.200^{(*)} \\
(0.117)\end{array}$ & $\begin{array}{l}0.183^{*} \\
(0.073)\end{array}$ & $\begin{array}{l}0.199^{*} \\
(0.091)\end{array}$ & $\begin{array}{l}0.008 \\
(0.078)\end{array}$ & $\begin{array}{l}0.028 \\
(0.109)\end{array}$ & $\begin{array}{l}0.238^{*} \\
(0.118)\end{array}$ \\
\hline $\begin{array}{l}\text { Mother: } \\
\text { Sports } \\
\text { interested }\end{array}$ & $\begin{array}{l}-0.136 \\
(0.138)\end{array}$ & $\begin{array}{l}0.052 \\
(0.147)\end{array}$ & $\begin{array}{l}0.058 \\
(0.100)\end{array}$ & $\begin{array}{l}0.090 \\
(0.135)\end{array}$ & $\begin{array}{l}0.011 \\
(0.179)\end{array}$ & $\begin{array}{l}0.095 \\
(0.112)\end{array}$ & $\begin{array}{l}0.099 \\
(0.140)\end{array}$ & $\begin{array}{l}0.226^{(*)} \\
(0.119)\end{array}$ & $\begin{array}{l}- \\
0.275^{(*)} \\
(0.168)\end{array}$ & $\begin{array}{l}0.424^{*} \\
(0.181)\end{array}$ \\
\hline
\end{tabular}

Table 7: The coefficient of intergenerational transfer variables, SUR method, filmgoing demand is always the

first equation and the filmgoing interest of the father and mother is included. $\left.{ }^{* * *},{ }^{* *},{ }^{*}\right)$ denote $0.1 \%, 1 \%, 5 \%$ or $10 \%$ statistical significance. Note: a positive sign indicates a positive influence 


\begin{tabular}{|c|c|c|c|c|c|c|c|c|c|c|c|c|}
\hline & & \multicolumn{11}{|c|}{ Outcome } \\
\hline \multirow{14}{*}{$\begin{array}{l}\text { त } \\
\text { TI } \\
\text { D } \\
0 \\
z\end{array}$} & & $\begin{array}{l}\text { Art } \\
\text { Gallery }\end{array}$ & Filmgoing & Opera & $\begin{array}{l}\text { Classical } \\
\text { music }\end{array}$ & Museum & Theatre & $\begin{array}{l}\text { Rock } \\
\text { music }\end{array}$ & Musicals & Sport & $\begin{array}{l}\text { Jazz } \\
\text { music }\end{array}$ & $\begin{array}{c}\# \\
\text { significant } \\
\end{array}$ \\
\hline & $\begin{array}{l}\text { Mother: } \\
\text { Reading }\end{array}$ & $0.450^{* * *}$ & $0.268^{* *}$ & $0.127^{(*)}$ & $0.228^{* *}$ & $0.375^{* *}$ & $0.365^{* * *}$ & $0.191^{*}$ & & & & 7 \\
\hline & $\begin{array}{l}\text { Mother: } \\
\text { Classical } \\
\text { music }\end{array}$ & $0.642^{* * *}$ & $0.443^{* *}$ & $0.582^{* * *}$ & $0.916^{* * *}$ & $0.860^{* * *}$ & & & & & $0.258^{*}$ & 6 \\
\hline & $\begin{array}{l}\text { Father: } \\
\text { Sport }\end{array}$ & & $0.185^{*}$ & $0.183^{*}$ & & $0.200^{(*)}$ & $0.199^{*}$ & $0.172^{(*)}$ & & $0.238^{*}$ & & 6 \\
\hline & $\begin{array}{l}\text { Mother: } \\
\text { Pop }\end{array}$ & & $0.315^{*}$ & & & & $0.303^{*}$ & $0.333^{*}$ & $0.217^{*}$ & & $0.243^{* *}$ & 5 \\
\hline & $\begin{array}{l}\text { Father: } \\
\text { Classical } \\
\text { music }\end{array}$ & $0.810^{* * *}$ & & $0.587^{* * *}$ & $0.565^{* * *}$ & $0.652^{* * *}$ & $0.332^{*}$ & & & & & 5 \\
\hline & $\begin{array}{l}\text { Mother: } \\
\text { Visual art }\end{array}$ & $0.812^{* * *}$ & $0.371^{* *}$ & $0.451^{* * *}$ & $0.491^{* * *}$ & $0.781^{* * *}$ & & & & & & 5 \\
\hline & $\begin{array}{l}\text { Mother: } \\
\text { Filmgoing }\end{array}$ & $0.290^{*}$ & $0.268^{*}$ & $0.170^{(*)}$ & & & $0.257^{*}$ & & & & & 4 \\
\hline & Father: Pop & & & $0.226^{*}$ & $0.321^{* *}$ & & & $0.353^{* *}$ & & & & 3 \\
\hline & $\begin{array}{l}\text { Father: } \\
\text { Visual art }\end{array}$ & $0.762^{* * *}$ & & & & $0.451^{*}$ & & & & $-0.471^{*}$ & & 3 \\
\hline & $\begin{array}{l}\text { Mother: } \\
\text { Sport }\end{array}$ & $-0.275^{(*)}$ & & & & & & & $0.226^{(*)}$ & $0.424^{*}$ & & 3 \\
\hline & $\begin{array}{l}\text { Father: } \\
\text { Reading }\end{array}$ & $0.245^{*}$ & & & $0.142^{(*)}$ & & & & & & & 2 \\
\hline & $\begin{array}{l}\text { Father: } \\
\text { Filmgoing }\end{array}$ & & $0.229^{*}$ & & & & & & $0.268^{* *}$ & & & 2 \\
\hline & $\begin{array}{c}\# \\
\text { significant }\end{array}$ & 8 & 7 & 7 & 6 & 6 & 5 & 4 & 3 & 3 & 2 & \\
\hline
\end{tabular}

Table 8: Statistically significant intergenerational transfer effects, note a positive sign indicates a positive influence. 


\begin{tabular}{|c|c|c|c|c|c|c|c|c|c|c|c|c|}
\hline & AGE & Filmgoing & $\begin{array}{l}\text { Rock } \\
\text { music }\end{array}$ & $\begin{array}{c}\text { Jazz } \\
\text { music }\end{array}$ & $\begin{array}{c}\text { Classical } \\
\text { music }\end{array}$ & Museum & Opera & Theatre & Musicals & $\begin{array}{c}\text { Art } \\
\text { Gallery }\end{array}$ & Sport & $\begin{array}{c}\# \\
\text { signif } \\
\end{array}$ \\
\hline $\begin{array}{l}\text { Father: Reading } \\
\text { interested }\end{array}$ & $\begin{array}{l}15-34 \\
35-54 \\
55-\end{array}$ & $\begin{array}{l}0.051 \\
0.038 \\
0.157\end{array}$ & $\begin{array}{l}0.007 \\
0.038 \\
0.053\end{array}$ & $\begin{array}{c}0.128 \\
0.038 \\
-0.080\end{array}$ & $\begin{array}{l}0.246 \\
0.167 \\
0.023\end{array}$ & $\begin{array}{l}0.613^{* *} \\
-0.119 \\
-0.008\end{array}$ & $\begin{array}{l}0.162 \\
0.049 \\
0.071\end{array}$ & $\begin{array}{c}0.038 \\
0.091 \\
-0.059\end{array}$ & $\begin{array}{c}0.140 \\
0.009 \\
0.254^{(*)}\end{array}$ & $\begin{array}{l}0.280 \\
0.150 \\
0.266\end{array}$ & $\begin{array}{c}-0.012 \\
0.003 \\
0.106\end{array}$ & $\begin{array}{l}1 \\
0 \\
1\end{array}$ \\
\hline $\begin{array}{l}\text { Mother: Reading } \\
\text { interested }\end{array}$ & $\begin{array}{l}15-34 \\
35-54 \\
55- \\
\end{array}$ & $\begin{array}{c}0.342^{(*)} \\
0.261^{(*)} \\
0.217 \\
\end{array}$ & $\begin{array}{c}0.137 \\
0.261^{(*)} \\
-0.012\end{array}$ & $\begin{array}{r}0.175 \\
0.103 \\
-0.041\end{array}$ & $\begin{array}{c}0.281^{(*)} \\
0.060 \\
0.295^{*}\end{array}$ & $\begin{array}{c}0.328 \\
0.604^{* *} \\
0.180\end{array}$ & $\begin{array}{l}0.073 \\
0.062 \\
0.189\end{array}$ & $\begin{array}{l}0.277^{(*)} \\
0.430^{* *} \\
0.407^{* *}\end{array}$ & $\begin{array}{c}0.058 \\
-0.105 \\
0.070\end{array}$ & $\begin{array}{c}0.356^{(*)} \\
0.397^{*} \\
0.509^{* *}\end{array}$ & $\begin{array}{c}0.047 \\
-0.068 \\
0.051\end{array}$ & $\begin{array}{l} \\
5 \\
3\end{array}$ \\
\hline $\begin{array}{l}\text { Father: Filmgoing } \\
\text { interested }\end{array}$ & $\begin{array}{l}15-34 \\
35-54 \\
55-\end{array}$ & $\begin{array}{c}0.190 \\
0.296^{(*)} \\
0.130\end{array}$ & $\begin{array}{c}0.340^{(*)} \\
-0.072 \\
0.001\end{array}$ & $\begin{array}{c}-0.186 \\
0.050 \\
0.255^{(*)}\end{array}$ & $\begin{array}{c}0.021 \\
0.078 \\
-0.104\end{array}$ & $\begin{array}{c}-0.056 \\
-0.064 \\
0.269\end{array}$ & $\begin{array}{r}0.028 \\
-0.023 \\
-0.198\end{array}$ & $\begin{array}{c}-0.132 \\
0.198 \\
0.222\end{array}$ & $\begin{array}{c}0.177 \\
0.151 \\
0.526^{*}\end{array}$ & $\begin{array}{c}-0.165 \\
-0.036 \\
0.075\end{array}$ & $\begin{array}{l}0.003 \\
0.118 \\
0.103\end{array}$ & $\begin{array}{l}1 \\
1 \\
2\end{array}$ \\
\hline $\begin{array}{l}\text { Mother: } \\
\text { Filmgoing } \\
\text { interested }\end{array}$ & $\begin{array}{l}15-34 \\
35-54 \\
55-\end{array}$ & $\begin{array}{c}0.370 \\
0.106 \\
0.372^{(*)}\end{array}$ & $\begin{array}{c}-0.043 \\
0.180 \\
-0.004\end{array}$ & $\begin{array}{c}0.039 \\
-0.010 \\
-0.047 \\
\end{array}$ & $\begin{array}{c}-0.199 \\
0.097 \\
0.410^{*}\end{array}$ & $\begin{array}{c}-0.066 \\
0.104 \\
0.167\end{array}$ & $\begin{array}{c}-0.035 \\
0.114 \\
0.315^{(*)}\end{array}$ & $\begin{array}{c}0.149 \\
0.095 \\
0.421^{(*)}\end{array}$ & $\begin{array}{l}-0.006 \\
-0.127 \\
-0.026\end{array}$ & $\begin{array}{c}-0.008 \\
0.321 \\
0.450^{(*)}\end{array}$ & $\begin{array}{c}-0.174 \\
0.059 \\
0.094 \\
\end{array}$ & $\begin{array}{l}0 \\
0 \\
5\end{array}$ \\
\hline $\begin{array}{l}\text { Father: Pop music } \\
\text { interested }\end{array}$ & $\begin{array}{l}15-34 \\
35-54 \\
55-\end{array}$ & $\begin{array}{c}0.340^{(*)} \\
0.133 \\
-0.076\end{array}$ & $\begin{array}{c}0.570^{*} \\
0.287 \\
-0.037\end{array}$ & $\begin{array}{c}0.172 \\
0.212 \\
-0.122\end{array}$ & $\begin{array}{c}0.092 \\
0.585^{* *} \\
0.099\end{array}$ & $\begin{array}{c}0.403 \\
0.609^{*} \\
-0.811^{*}\end{array}$ & $\begin{array}{c}0.095 \\
0.501^{* *} \\
-0.146\end{array}$ & $\begin{array}{c}0.305 \\
0.117 \\
-0.279\end{array}$ & $\begin{array}{c}-0.041 \\
0.410^{*} \\
0.119\end{array}$ & $\begin{array}{c}0.417^{(*)} \\
0.016 \\
-0.523\end{array}$ & $\begin{array}{r}0.230^{(*)} \\
0.337^{* *} \\
-0.424^{(*)}\end{array}$ & $\begin{array}{l}4 \\
5 \\
2\end{array}$ \\
\hline $\begin{array}{l}\text { Mother: Pop } \\
\text { music interested }\end{array}$ & $\begin{array}{l}15-34 \\
35-54 \\
55-\end{array}$ & $\begin{array}{c}0.182 \\
0.527^{* *} \\
0.265\end{array}$ & $\begin{array}{c}0.202 \\
0.468^{*} \\
0.400^{* *}\end{array}$ & $\begin{array}{l}0.262^{*} \\
0.269^{(*)} \\
0.209 \\
\end{array}$ & $\begin{array}{c}0.381^{*} \\
0.065 \\
-0.037 \\
\end{array}$ & $\begin{array}{c}0.211 \\
-0.052 \\
-0.228 \\
\end{array}$ & $\begin{array}{l}0.123 \\
0.002 \\
0.041\end{array}$ & $\begin{array}{c}0.335^{(*)} \\
0.288 \\
0.396\end{array}$ & $\begin{array}{c}0.257^{(*)} \\
0.330^{*} \\
-0.155\end{array}$ & $\begin{array}{c}0.024 \\
-0.003 \\
-0.014\end{array}$ & $\begin{array}{c}0.267^{(*)} \\
-0.005 \\
0.277\end{array}$ & $\begin{array}{l}5 \\
4 \\
1\end{array}$ \\
\hline $\begin{array}{l}\text { Father: Classical } \\
\text { music interested }\end{array}$ & $\begin{array}{l}15-34 \\
35-54 \\
55-\end{array}$ & $\begin{array}{c}0.074 \\
-0.148 \\
0.438\end{array}$ & $\begin{array}{c}0.765^{(*)} \\
-0.216 \\
0.282^{(*)} \\
\end{array}$ & $\begin{array}{c}0.299^{(*)} \\
0.141 \\
0.016\end{array}$ & $\begin{array}{c}0.462^{(*)} \\
0.556^{*} \\
0.363 \\
\end{array}$ & $\begin{array}{c}0.964^{* *} \\
0.537^{(*)} \\
0.363 \\
\end{array}$ & $\begin{array}{c}0.763^{* * *} \\
0.598^{* *} \\
0.263\end{array}$ & $\begin{array}{c}0.655^{*} \\
0.182 \\
0.230\end{array}$ & $\begin{array}{c}0.385^{(*)} \\
0.186 \\
0.065\end{array}$ & $\begin{array}{c}0.730^{*} \\
-0.343 \\
1.168^{* * *}\end{array}$ & $\begin{array}{l}0.049 \\
0.036 \\
0.209\end{array}$ & $\begin{array}{l}1 \\
8 \\
3 \\
2\end{array}$ \\
\hline $\begin{array}{l}\text { Mother: Classical } \\
\text { music interested }\end{array}$ & $\begin{array}{l}15-34 \\
35-54 \\
55-\end{array}$ & $\begin{array}{c}0.531^{*} \\
0.528^{*} \\
0.220\end{array}$ & $\begin{array}{c}-0.113 \\
0.346 \\
-0.326^{*}\end{array}$ & $\begin{array}{c}0.302^{(*)} \\
0.213 \\
0.275\end{array}$ & $\begin{array}{c}1.030^{* * *} \\
0.489^{*} \\
1.343^{* * *}\end{array}$ & $\begin{array}{c}1.103^{* * *} \\
0.833^{* *} \\
0.585\end{array}$ & $\begin{array}{c}0.710^{* * *} \\
0.210 \\
0.866^{* * *}\end{array}$ & $\begin{array}{l}0.180 \\
0.165 \\
0.467\end{array}$ & $\begin{array}{c}0.098 \\
-0.107 \\
0.303\end{array}$ & $\begin{array}{c}0.470^{(*)} \\
0.662^{*} \\
0.601^{(*)}\end{array}$ & $\begin{array}{c}0.337^{(*)} \\
-0.066 \\
0.109\end{array}$ & $\begin{array}{l}7 \\
4 \\
4\end{array}$ \\
\hline $\begin{array}{l}\text { Father: Visual } \\
\text { arts interested }\end{array}$ & $\begin{array}{l}15-34 \\
35-54 \\
55-\end{array}$ & $\begin{array}{c}0.238 \\
0.421^{(*)} \\
-0.472\end{array}$ & $\begin{array}{c}0.602 \\
0.126 \\
-0.278\end{array}$ & $\begin{array}{l}-0.015 \\
-0.032 \\
-0.153\end{array}$ & $\begin{array}{c}0.467^{(*)} \\
0.298 \\
-0.206\end{array}$ & $\begin{array}{c}0.861^{*} \\
0.507 \\
-0.330\end{array}$ & $\begin{array}{c}0.131 \\
0.245 \\
-0.157\end{array}$ & $\begin{array}{c}0.690^{*} \\
0.330 \\
-0.348\end{array}$ & $\begin{array}{l}0.260 \\
0.154 \\
0.165\end{array}$ & $\begin{array}{c}1.116^{* * *} \\
0.438 \\
0.473\end{array}$ & $\begin{array}{l}-0.046 \\
-0.058 \\
-0.041\end{array}$ & $\begin{array}{l}4 \\
1 \\
0\end{array}$ \\
\hline $\begin{array}{l}\text { Mother: Visual } \\
\text { arts interested }\end{array}$ & $\begin{array}{l}15-34 \\
35-54 \\
55-\end{array}$ & $\begin{array}{c}0.289 \\
0.201 \\
0.717^{*}\end{array}$ & $\begin{array}{c}-0.450 \\
-0.098 \\
0.168\end{array}$ & $\begin{array}{c}0.098 \\
-0.071 \\
0.429^{*}\end{array}$ & $\begin{array}{c}0.377^{(*)} \\
0.456^{*} \\
0.789^{* *}\end{array}$ & $\begin{array}{l}0.928^{* * *} \\
0.472^{(*)} \\
1.298^{* * *}\end{array}$ & $\begin{array}{c}0.349^{*} \\
0.392^{*} \\
0.700^{* *}\end{array}$ & $\begin{array}{c}0.018 \\
-0.046 \\
0.584^{(*)}\end{array}$ & $\begin{array}{c}0.044 \\
-0.009 \\
0.148\end{array}$ & $\begin{array}{c}0.527^{*} \\
0.839^{* * *} \\
1.295^{* * *}\end{array}$ & $\begin{array}{c}-0.277^{(*)} \\
0.162 \\
0.098\end{array}$ & $\begin{array}{l}5 \\
4 \\
7\end{array}$ \\
\hline $\begin{array}{l}\text { Father: } \\
\text { interested }\end{array}$ & $\begin{array}{l}15-34 \\
35-54 \\
55-\end{array}$ & $\begin{array}{c}-0.085 \\
0.192 \\
0.353^{*}\end{array}$ & $\begin{array}{c}-0.041 \\
0.320^{*} \\
0.164^{(*)}\end{array}$ & $\begin{array}{l}-0.048 \\
-0.058 \\
0.267^{*}\end{array}$ & $\begin{array}{c}-0.054 \\
0.243^{(*)} \\
0.147\end{array}$ & $\begin{array}{c}-0.002 \\
0.403^{*} \\
0.075\end{array}$ & $\begin{array}{c}-0.025 \\
0.221^{(*)} \\
0.288^{*}\end{array}$ & $\begin{array}{l}-0.187 \\
0.354^{*} \\
0.320^{*}\end{array}$ & $\begin{array}{c}-0.042 \\
0.052 \\
-0.037\end{array}$ & $\begin{array}{c}0.047 \\
0.084 \\
-0.081\end{array}$ & $\begin{array}{c}0.228^{(*)} \\
0.223^{*} \\
0.320^{*}\end{array}$ & $\begin{array}{l}1 \\
6 \\
6\end{array}$ \\
\hline $\begin{array}{l}\text { Mother: } \\
\text { interested }\end{array}$ & $\begin{array}{l}15-34 \\
35-54 \\
55-\end{array}$ & $\begin{array}{c}0.176 \\
-0.369^{(*)} \\
-0.127\end{array}$ & $\begin{array}{c}-0.113 \\
0.203 \\
0.136\end{array}$ & $\begin{array}{c}0.306^{*} \\
0.124 \\
-0.334^{(*)}\end{array}$ & $\begin{array}{l}0.456^{*} \\
-0.080 \\
-0.025\end{array}$ & $\begin{array}{c}0.452 \\
-0.352 \\
0.141\end{array}$ & $\begin{array}{c}0.180 \\
-0.038 \\
0.356\end{array}$ & $\begin{array}{c}0.453^{(*)} \\
-0.258 \\
0.263\end{array}$ & $\begin{array}{l}0.164 \\
0.169 \\
0.419\end{array}$ & $\begin{array}{c}0.011 \\
-0.604^{*} \\
-0.042\end{array}$ & $\begin{array}{c}0.505^{* *} \\
0.470^{* * *} \\
0.287\end{array}$ & $\begin{array}{l}4 \\
3 \\
1\end{array}$ \\
\hline
\end{tabular}

Table 9: Intergenerational transfer effects, different age groups, SUR method, ${ }^{* * *}, * *,, 0$ denote $0.1 \%, 1 \%, 5 \%$ or

$10 \%$ statistical significance. Note: a negative sign indicates a positive influence

Appendix
\begin{tabular}{|l|l|l|}
\hline & Net personal incomes, $\mathbf{n}=\mathbf{1 3 3 6}$ & Net household incomes, $\mathbf{n}=\mathbf{1 0 2 6}$ \\
\hline Vocational education & $154.60(91.18)^{* *}$ & $-128.57(160.50)$ \\
\hline College degree & $494.62(98.33)^{* * *}$ & $430.59(173.77)^{*}$ \\
\hline Bachelor's degree & $540.18(125.45)^{* * *}$ & $452.93(220.39)^{*}$ \\
\hline Master's degree & $906.78(105.51)^{* * *}$ & $946.50(186.15)^{* * *}$ \\
\hline Doctoral degree & $1468.20(218.29)^{* * *}$ & $1225.40(382.55)^{* *}$ \\
\hline Female & $-523.21(62.15)^{* * *}$ & $-307.34(109.59)^{* *}$ \\
\hline Age: $15-24$ & $-893.37(122.08)^{* * *}$ & $390.91(224.95)^{* *}$ \\
\hline Age: $25-34$ & $-275.48(106.35)^{* *}$ & $-392.25(186.96)^{*}$ \\
\hline Age: $45-54$ & $84.66(101.36)$ & $-25.16(177.47)$ \\
\hline Age: $55-64$ & $-151.45(98.27)$ & $-433.85(176.46)^{*}$ \\
\hline Age: $65-$ & $-531.78(111.05)^{* * *}$ & $-830.86(213.20)^{* * *}$ \\
\hline Common law marriage & & $2670.97(148.19)^{* * *}$ \\
\hline Marriage & & $2880.68(130.13)^{* * *}$ \\
\hline Hours worked/week & & $12.93(3.05)^{* * *}$ \\
\hline Constant & $1645.02(109.36)^{* * *}$ & $-23.35(112.36)$ \\
\hline $\mathrm{R}^{2}$ & 0.186 & 0.353 \\
\hline F & $29.90^{* * *}$ & $55.02^{* * *}$ \\
\hline
\end{tabular}

Table 10: Net personal or household incomes, determination equations, OLS 


\begin{tabular}{|l|l|}
\hline & Exercise any sports \\
\hline Vocational education & $0.037(0.111)$ \\
\hline College degree & $0.375(0.125)^{* *}$ \\
\hline Bachelor's degree & $0.521(0.174)^{* *}$ \\
\hline Master's degree & $0.631(0.148)^{* * *}$ \\
\hline Doctoral degree & $0.513(0.309)^{(*)}$ \\
\hline Female & $0.254(0.081)^{* *}$ \\
\hline Age: $15-24$ & $0.212(0.180)$ \\
\hline Age: $25-34$ & $-0.184(0.147)$ \\
\hline Age: $35-44$ & Ref \\
\hline Age: $45-54$ & $-0.083(0.141)$ \\
\hline Age: $55-64$ & $-0.298(0.132)^{*}$ \\
\hline Age: $65-$ & $-0.338(0.147)^{*}$ \\
\hline Marital status: Single & $-0.219(0.151)$ \\
\hline Marital status: Married & $-0.172(0.119)$ \\
\hline Father sporty active & $0.175(0.084)^{*}$ \\
\hline Mother sporty active & $0.238(0.144)^{(*)}$ \\
\hline Constant & $0.677(0.181)^{* * *}$ \\
\hline McFadden Pseudo R ${ }^{*}:$ & 0.0646 \\
\hline$\chi^{2}$-test: & 89.995 \\
\hline
\end{tabular}

Table 11: A probit equation for exercise any sports.

\begin{tabular}{|l|l|l|}
\hline & Employed (probit) & Working hours per week (OLS) \\
\hline Constant & $0.173(0.143)$ & $22.598(0.845)^{* * *}$ \\
\hline $\begin{array}{l}\text { Owner-occupied home with } \\
\text { mortgage }\end{array}$ & $0.244(0.086)^{* *}$ & $4.238(0.511)^{* * *}$ \\
\hline Vocational education & $0.335(0.113)^{* *}$ & $4.330(0.670)^{* * *}$ \\
\hline College degree & $0.514(0.125)^{* * *}$ & $5.564(0.724)^{* * *}$ \\
\hline Bachelor's degree & $0.406(0.154)^{* *}$ & $4.288(0.923)^{* * *}$ \\
\hline Master's degree & $0.542(0.133)^{* * *}$ & $4.784(0.776)^{* * *}$ \\
\hline Doctoral degree & $0.359(0.284)$ & $5.741(1.605)^{* * *}$ \\
\hline Female & $-0.194(0.079)^{*}$ & $-3.784(0.457)^{* * *}$ \\
\hline Age: $15-24$ & $-0.759(0.147)^{* * *}$ & $-15.365(0.915)^{* * *}$ \\
\hline Age: $25-34$ & $-0.198(0.131)$ & $-3.076(0.784)^{* * *}$ \\
\hline Age: $45-54$ & $0.236(0.134)^{(*)}$ & $2.850(0.753)^{* * *}$ \\
\hline Age: $55-64$ & $-0.668(0.123)^{* * *}$ & $-11.113(0.754)^{* * *}$ \\
\hline Age: $65-$ & $-2.156(0.178)^{* * *}$ & $-26.113(0.864)^{* * *}$ \\
\hline & & \\
\hline $\begin{array}{l}\text { Inverse Mills ratio (obtained from } \\
\text { probit) }\end{array}$ & & $21.386(0.313)^{* * *}$ \\
\hline & McFadden Pseudo $\mathrm{R}^{2}: 0.233$ & $\mathrm{R}^{2}: 0.838$ \\
\hline & $\chi^{2}$-test: $442.16^{* * *}$ & $\mathrm{~F}-\operatorname{test}: 554.70^{* * *}$ \\
\hline
\end{tabular}

Table 12: A probit equation for being employed and working hours per week (OLS) determination equation 